\title{
Determinants and Sensitivity of Credit Ratings: A Panel Data Analysis
}

\author{
Onnuri Ha, Master's Course, Inha University \\ Jae-Joon Han ${ }^{* *}$, Professor, Inha University
}

\begin{abstract}
$\langle$ Abstract $\rangle$
Using panel ordinal logit model from 2009 to 2019, this study analyzed the determinants of corporate bond credit ratings. Although credit rating agencies consider both market and financial factors to determine rating (Agency Rating, AR), most literature only considers the effect of financial factors on AR. This study attempts to fill this gap by adding market risk measure and analyzing the effect on bond-implied rating (BIR) determination. We also analyze the sensitivity difference between AR and BIR. Our finding reveals that both AR and BIR are significantly improved when volatilities in sales and operating profit increase. Regarding rating inflation (mismatches), increases in assets further improve AR, while net exports and industrial activity lower BIR, leading to rating inflation. The increase in M2 (broad measure of money supply) worsens AR while improving BIR, leading to rating deflation. Finally, the effects of large enterprises, recession, and construction industries on the rating inflation is analyzed through dummy variables. The results revealed that, unlike in previous studies, the dummy variable of large enterprises was not significant. The relative worsening of BIR during the recession resulted in rating inflation. Finally, the stigma effect on construction industry was observed, which shows significant rating inflation.
\end{abstract}

Keywords: Credit Rating Agency; Agency Rating; Bond Implied Rating; Credit Rating Inflation; Ordered Logit Model

JEL Classification: D82, G24, L15

* This work was supported by INHA UNIVERSITY Research Grant.

** Corresponding Author. Address: Inha University, Department of Global Finance and Banking, 100, Inha-ro, Michuhol-Gu, Incheon, Korea, 22212; E-mail: jjhan@inha.ac.kr;

Tel: +82-32-860-7817; Fax:+82-32-866-6877.

Received: July 21, 2020; Revised: October 7, 2020; Accepted: October 27, 2020 


\section{패널자료를 활용한 신용평가등급의 결정요인과 민감도 분석"}

하온누리 (인하대학교 석사과정)

한 재 준 (인하대학교 교수)**

국문요약 본 고는 회사채 신용등급의 결정요인을 패널 순서형로짓 모형으로 분석하였다. 신용평가사의 등급결정시에는 재무요인과 더불어 기업들이 직면한 시장위험도 고려되지만, 기존 연구는 재무요인을 설명변수로 한 신용등급 $(\mathrm{AR})$ 분석들이 대부분이었다. 이에 본 고는 재무요인과 시장위험, 양자 모두를 설명변수로 하여 $\mathrm{AR}$ 뿐만 아니라 채권내재등급(BIR) 결정에 미치는 영향을 분석하였다. 분석결과 상당수 재무변수들은 선행연구처럼 $\mathrm{BR}$ 등급결정에도 유사한 영향력을 미치고, 매출액.영업이익 변동성 확대가 신용등급을 개선시킨다는 것을 새로이 발견하였다. 양 등급간의 차이에 대한 민감도 분석에서는 기존 연구와 달리 대기업의 등급인플레이션이 유의하지 않았다. 반면에 경기후퇴기와 건설업에서는 등급 인플레이션이 여전히 목격되었다. 등급불일치에 대한 민감도 분석에서 자산의 확대는 $\mathrm{AR}$ 을 더 많이 개선시키고, 순수출·산업활동지수의 상승은 $\mathrm{BRR}$ 을 더욱 하락시킴에 따라 등급인플레이션이 초래되었다. 한편 $\mathrm{M} 2$ 의 증가는 $\mathrm{AR}$ 등급 악화, $\mathrm{BIR}$ 등급 개선으로 등급디플레이션을 초래하고 있었다. 마지막으로 설명변수가 등급개선, 등급불일치 발생에 미치는 영향은 오즈비(Odds ratio)로 계량화 해보았다.

핵심 단어 : 신용평가사, 신용등급, 채권내재등급, 등급인플레이션, 순서형로짓

JEL 분류기호: D82, G24, L15

* 본 논문은 인하대학교의 교내연구비 지원을 통해 작성되었으며, 실증분석에 사용된 $\mathrm{BIR}$ 자료를 제공해 준 나이스P\&I와 논문의 완성도를 높이는데 도움을 주신 익명의 두 분의 심사자께 감사드리고, 남은 오류는 전적으로 저자들의 책임이다.

** 연락담당 저자. 주소: 인천광역시 미추홀구 인하로 100 , 인하대학교 경영대학 글로벌금융학과, 22212 ; E-mail: jjhan@inha.ac.kr; Tel: 032-860-7817; Fax: 032-866-6877. 


\section{1. 서론}

자본시장은 자금을 필요로 하는 기업과 잉여자금을 운영하는 투자자들이 서로 만나는 시장이다. 그리고 금융기관(financial intermediary)은 자금시장에서 수요자와 공급자간에 정보의 불확실성을 해소하여 매칭시키는 중개자의 역할을 수행한다. 최근 DLF 사태 등으로 금융기관이 이 역할을 제대로 수행하는지가 투자자 보호 이슈와 맞물려 제기 되기도 하였다. 기업의 주요한 자금조달 수단은 주식과 회사채 발행이다. 이 가운데 회사채 발행과 관련하여 신용평가사(이하 신평사)는 원리금의 상환가능성을 분석한 뒤, 그 결과를 $\mathrm{AAA}, \mathrm{BB}$ 와 같은 신용등급으로 투자자들에게 공시하여 정보비대칭성을 해소하고 기업의 자금조달을 가능하게 하는 역할을 수행한다. 이처럼 신평사는 투자자들의 탐색 비용을 줄여 금융시장의 효율성을 제고시키는 인프라 역할을 수행하기 때문에 소위 축구의 골키퍼처럼 자본시장의 문지기(gate keeper)라고 일컬어지고 있다.

국제적인 신평사로는 S\&P, Moody's, Fitch가 있으며 국내에서는 나이스신용평가, 한국신용평가, 한국기업평가 이상 3 개의 신평사가 대표적이다. 1997년 외환위기 이전 담보부이던 국내 회사채 시장이 오늘날 무보증시장으로 변모된 데는 신평사의 역할이 주요했다. 이 결과 회사채 발행 잔액은 2019년 말기준 813조 원(국고채 제외)으로 지난 20년간 6배 이상 증가하였다.1)

신평사의 웹사이트에 따르면 신용등급(Agency Rating, AR) 산정은 다음의 방식으로 이루어진다.2) 원리금 지급의 불확실성을 사업위험과 재무위험으로 나누어 평가한 뒤 이를 등급화하여 공시한다. 사업위험에는 산업의 위험, 시장지위, 경쟁력, 운영의 효율성, 경영관리능력 등이 고려되고, 재무위험으로는 기업의 재무정책, 수익성, 유동성, 재무구조, 자산의 질, 현금 흐름의 적정성, 자본적정성이 고려된다고 한다. 다시 말해 회사채 원리금 회수와 관련된 사업의 안정성, 기업의 재무구조, 수익성, 유동성 등을 전반적으로 반영한다.

한편, 1997년 아시아 금융위기와 2008년 미국의 서브프라임 모기지 사태시 글로벌 신평사의 신용등급(AR)이 부적절했다는 비난이 제기되었다. 반면에 국내 신평사들은 주로 회사채를 취급하고 있고, 글로벌 신평사와 달리 구조화 채권에 대한 평가가 적어서 등급인플레이션 우려가 없다고 안도하였다. 하지만 2013년 동양증권 사태, 2014년 대우조선 분식회계 우려와 한진해운 파산 등 일련의 사건이 발생하면서 국내 신평사도 등급인플레이션 등의 문제들에서 자유롭지 못하다는 비판이 제기되었다. 당시 부각된 구조적인 문제점은 다음의 4 가지이다. 첫째, 평가대상 회사가 신평사에게 수수료를 지급하는 소위 발행자지급모형(issuer-pays structure)으로 인한 등급쇼핑과 등급인플레이션 현상이다. 둘째, 과점적인 신용평가시장의 구조이다. 국내는 물론 국제시장에서도 3 개사가 독과점하는 구조이다. 셋째, 구조화상품과 같이 복잡한 금융상품이 등장하면서 신평사의 평가 능력에 한계가 발생한다는 지적이다. 넷째, 대우조선해양과 같이 장기의 수주 사이클을 가진 업종에 대한 등급의 신뢰성 문제다. 대우조선해양 분식회계 사태로 지정감사인제도의 담합, 등급인플레이션이 문제시되었는데, $\mathrm{AR}$ 등급의 속성상 경기하강기에

1) 금융감독원 ‘자본시장 위험 분석 보고서」, 2020.05.

2) 나이스신용평가 「신용평가일반론」, 2020.06. 
Determinants and Sensitivity of Credit Ratings

적시에 등급이 하락되기 어렵다는 구조적인 문제가 있다. 이 때문에 발행자지급모형을 대체할 투자자지급모형이 논의되었지만 실현가능성 낮고, $\mathrm{AR}$ 등급의 가치를 부인하기 어렵다는 딜레마가 있다.

그럼에도 불구하고 신평사 등급의 정확성, 적시성을 검증하기 위한 대안은 모색될 필요가 있다. 그 대안 중 하나가 MIR(Market Implied Rating)의 일종인 BIR(Bond Implied Rating)이다. 원리금 또는 발행자의 채무상환능력이 금리 스프레드로 반영된다는 점에 착안해서, 채권의 유통수익률을 근거로 사후적으로 신용위험을 평가한 등급이다. AR(Agency Rating)은 채권 발행시 신평사가 사전에 산정하는 등급이란 점에서 차이가 있다. $\mathrm{BIR}$ 은 $\mathrm{AR}$ 이 결여하기 쉬운 적시성과 효율성을 고양시킬 수 있다는 점에서 보완지표로 각광을 받고 있다.3)

하지만 $\mathrm{BIR}$ 은 유통수익률을 베이스로 하기 때문에 시장 유동성과 경기에 영향을 받을 수밖에 없다. 이 결과 발행수익률을 결정하는 $\mathrm{AR}$ 과의 차이는 불가피하다. 어쨌든 발행수익률에서의 등급순위가 유통수익률에서도 유지된다면 큰 문제는 없다. 그러나 모든 채권물의 유통스프레드의 폭과 순위가 항상 발행물의 순서와 동일하지 못하다는데 딜레마가 있다. 즉, 특정 기업이나 업종의 유통스프레드가 시기별로 발행수익률과 달라질 수 있다. 또한 AR은 등급의 안정성이 강조되기 때문에 $\mathrm{BIR}$ 과 달리 등급변경이 자주 이루어지지 못한다. 이러한 차이점이 큰 업종도 출현하기 마련이다. 이처럼 $\mathrm{BIR}$ 은 $\mathrm{AR}$ 과는 등급의 도출 원리, 도출시기, 그리고 등급의 안정성이 상이하기 때문에 일정정도 양 등급간 불일치 발생은 불가피하다.

이 점에 착안하여 본 연구는 다음의 분석을 진행한다. 먼저 재무제표 변수들과 시장위험을 나타내는 산업활동지수 및 금리 등과 같은 거시경제변수가 $\mathrm{AR}, \mathrm{BIR}$ 등급에 미치는 영향을 각각 분석한다. 또한 이들 설명변수들이 $\mathrm{AR}, \mathrm{BIR}$ 등급결정에 미치는 민감도 차이(difference in sensitivity)에 대해 분석한다. 이를 통해 양 등급 간의 불일치, 소위 등급인플레이션이나 디플레이션 발생 원인을 규명해 본다. 참고로 본 고에서 사용하는 등급인플레이션이란 “신용등급(AR)이 실제 적절한 등급에 비해 우수하게 평가되는 현상”을 지칭한다. 관련해서 본 고에서는 통상의 신용등급은 신용평가가사 발표하는 $\mathrm{AR}$ 등급으로 해석하고, 그리고 내재 등급은 BIR(Bond Implied Rating)등급으로 간주하였다.4)

본 연구에 사용된 BIR등급은 나이스피앤아이(National Information \& Credit Evaluation, $\mathrm{NICE}$ )에서 제공받았다. 2009년부터 2019년까지 11년 동안의 나이스신용평가의 신용등급(AR)을 기반으로, 나이스피앤아이가 시장수익률을 기초로 산출한 월별 채권내재금리(BIR)가 동시에 존재하는 기업을 대상으로 하였다. 그리고 피평가기업의 재무제표자료는 KIS-VALUE에서 추출하여 매칭시켰다.

3) $\mathrm{BIR}$ 은 사후적으로 시장에서 평가된 발행기업의 신용위험을 등급화된 기호로 표현하여 $\mathrm{AR}$ 과의 비교 가능성을 확보하고, 이 과정에서 추가적인 정보를 전달한다.

4) 이에 따라 $\mathrm{AR}$ 등급이 $\mathrm{BIR}$ 등급보다 높은 경우를 등급인플레이션, 그 반대인 경우를 등급디플레이션으로 정의하였다. 한편 이러한 방식은 $\mathrm{BIR}$ 등급의 변화가 $\mathrm{AR}$ 등급보다 잦기 때문에 $\mathrm{AR}$ 등급과 $\mathrm{BIR}$ 등급간의 불일치가 자주 발생하면서 등급인플레이션이나, 디플레이션의 발생 빈도를 높일 수 있다는 문제점이 지적될 수 있다. 
한국증권학회지 제49권 6호 (2020)

$\mathrm{AR}$ 신용등급과 관련된 국내연구는 제법 축적되었다. 재무변수와 BIR에 대한 연구도 2016년 부터 시작되고 있으나 2010년 초반까지 데이터를 대상으로 한 것들이어서 패널자료를 활용한 분석은 거의 전무하다. 반면에 본고는 2019년까지 축척된 시계열자료를 사용하여, 발행 기업에 내재된 고유한 특성을 패널분석으로 통제한 뒤 재무변수와 거시경제변수가 등급결정에 미치는 영향을 분석하였다.

본 연구의 주요한 결과는 다음과 같다. 재무변수 중 부채의 증가는 $\mathrm{BIR}$ 과 $\mathrm{AR}$ 신용등급에 유의하게 부정적인 것으로 나타났다. 반면에 자산, 순이익, 매출액, 그리고 매출액과 영업이익 표준편차의 확대는 BIR과 $\mathrm{AR}$ 신용등급 모두를 유의하게 개선시켰다. 특히 매출액 표준편차 등 변동성 확대가 신용등급을 개선시킨다는 것은 본 고의 새로운 발견이다. 일반적으로 변동성 확대는 기업의 장래 예측에 불확실성을 고조시키므로 신용평가에 부정적이라고 알려져 있다. 그러나 패널분석기법으로 관측되지 않는 기업의 고유한 특성을 통제할 경우 매출액(및 영업 이익)의 변동성 확대는 기업의 신용등급 개선 효과를 초래하는 것으로 나타났다. 이러한 신용등급 개선 효과가 나타난 배경으로는 매출액과 영업이익의 변동성 확대가 해당기업의 위험성 증대 이외에도 시장내 지위, 경쟁력(신용평가항목 중 정성적인 항목) 증대에서 비롯된 것이란 해석도 가능할 것이다.

다음으로는 $\mathrm{BIR}$ 이 거시경제 상황과 시장 유동성에 $\mathrm{AR}$ 과 달리 민감하다는 속성에 착안하여 $\mathrm{AR}$ 과의 비교, 즉 양 등급의 설명변수에 대한 민감도 차이를 분석하였다. 이 과정에서 등급불일치의 발생의 원인 규명과 새로운 해석이 가능하였다. 예를 들어 순상품교역조건지수가 개선될 경우 $\mathrm{AR}$ 과 $\mathrm{BIR}$ 등급 모두가 악화되는데 $\mathrm{BIR}$ 등급이 더 악화되기 때문에 등급인플레이션이 초래 되었다. 반면에 산업활동지수는 $\mathrm{AR}$ 등급은 개선되지만 $\mathrm{BIR}$ 등급은 악화됨에 따라 등급인플레이션이 발생하였다. 가장 흥미로운 발견은 유동성지표인 $\mathrm{M} 2$ 이다. $\mathrm{M} 2$, 즉 시중유동성이 늘어날 경우 $\mathrm{BIR}$ 등급은 개선되지만 $\mathrm{AR}$ 등급은 악화되면서 등급디플레이션이 발생하고 있었다. 이에 대한 해석으로는 시중유동성이 확대될 때, 금리가 하락하면서 $\mathrm{BIR}$ 등급산정의 기초인 금리스프레드가 축소되기 때문에 $\mathrm{BIR}$ 에 기반한 신용등급은 전반적으로 개선되지만, 신평사(AR)는 이러한 유동성 확대시 오히려 보수적으로 등급을 평가하려는 경향이 나타나는데, 이것이 등급디플레이션 현상으로 표출된다고 볼 수 있다. 본 고에서는 신용등급결정 분석 시 본 고는 프로빗이 아닌 로짓 모형을 사용하였는데, 그 장점으로 오즈비(Odds ratio)를 구하여 설명변수 한 단위 변화가 종속변수(AR, BIR등급 및 양 등급간 차이)에 미치는 영향을 계량화할 수 있다는 점이다. 실제 $\mathrm{M} 2$ (유동성)가 종속변수에 미치는 영향을 오즈비로 측정해 보면 다음과 같다. $\mathrm{M} 2$ 가 $1 \%$ 증가 시, $\mathrm{BIR}$ 등급에 대한 오즈비는 0.002 배로 1 보다 작은 반면, AR등급에 대한 오즈비는 1.156 으로 나타났다. 그 결과 등급인플레이션(등급불일치)에 대한 오즈비는 1 보다 작아져, 등급디플레이션 가능성이 큰 것으로 나타났다. 산업활동지수와 순상품교역조건지수의 등급인플레이션에 대한 오즈비는 모두 1 보다 큰 값을 보이여 동 지수 증가 시, 등급인플레이션 가능성이 높게 나타났다. 재무변수 가운데 자산(및 유동자산), 부채는 등급인플레이션을 초래하고, 매출액, 감가상각 및 매출액표준편차는 그 반대로 등급디플레이션을 초래하는 것으로 나타났다. 특히 부채의 1 조 증가 시, 등급인플레이션에 대한 오즈비는 1.02 로 등급인플레이션 가능성이 더 높고, 매출액 
Determinants and Sensitivity of Credit Ratings

1 조 증가 시 등급인플레이션에 대한 오즈비는 0.95 로 1 보다 작아 등급디플레이션 가능성이 더 큰 것으로 보인다.

이하에서 본 논문의 기술은 다음과 같다. 제 2 장에서는 기존문헌을 개관한다. 제 3 장에서는 연구모형을 제시하고 연구표본을 개괄한다. 제 4 장에서는 연구의 결과를 요약하면서 시사점을 도출하였다. 제 5 장은 결론이다.

\section{2. 선행연구}

신평사의 신용등급은 회사채 발행 기업에 대한 정보를 투자자들에게 제공하고 정보의 비대칭성을 완화시킴으로써 자본시장의 발전에 기여한다. 신용등급이란 채권 발행자의 채무불이행 위험을 파악하는 지표로 사용된다. 그런데 2008년 금융위기 시 글로벌 신평사들이 구조화 채권에 내재된 위험을 파악하지 못한 채 높은 신용등급을 부여하였다는 비판, 즉 신용등급의 신뢰성 문제가 제시되기 시작하였다. 신용등급이 신뢰성을 갖기 위해서 평가의 정확성이 확보되어야 하는데, 발행자지급모델에서는 발행자가 우호적인 등급을 판정할 신평사를 선정하는, 소위 등급쇼핑 유인이 존재한다. 신평사 또한 이를 의식할 경우 평가의 독립성이 훼손되는, 등급인플레이션 우려가 있다.

또한 평가등급의 적시성이 결여된다는 비판도 있다. 신평사의 AR은 안정성(Stability)을 우선시하게 되는데, 이 때문에 경기순환주기(Through the Cycle)에서 적시성이 결여된다는 비판도 있다. 신평사는 수시로 신용등급을 변화시킬 경우 투자 판단지표로 신뢰성이 결여되고, 발행자가 자금조달에 난관이 발생한다고 항변한다.5) 하지만 국내에서도 2013년 동양증권, 2014년 대우조선해양 분식회계 사건이 발생하면서 신평사의 등급의 정확성과 더불어 적시성 논란이 제기되기도 하였다.

신용평가사의 등급과 관련된 국내 연구들은 다음의 4 가지 방면에서 이루어졌다. 첫째, 신용평가사의 등급(AR)과 재무변수간 연관성에 대한 연구들이다. Shin(1989)은 한국신용평가의 기업어음 $(\mathrm{CP})$ 신용등급을 종속변수로 삼고, 설명변수로 부채비율, 총자산순이익률, 매출액증가율, 총자산회전율을 설정하여 동 회귀분석이 유의함을 보였다. Na and $\operatorname{Jin}(2003)$ 은 외환위기 이후 596 개 상장기업을 대상으로 한 로짓분석에서 배당률과 총자산 변수가 신용등급에 정(+)의 영향을, 금융비용/총비용 비율과 금융비용/매출액 비율이 음(-)의 영향을 미친다는 것을 보였다. Park et al.(2008)은 11 개 재무변수6)를 지표화한 뒤, 동 지표와 신용등급 간 유의한 정(+)의 관계가 있음을 보였다. 이 밖에 Jeon and Lee(2015)는 영업부채에 비해 금융부채가 신용등급 결정에 영향력이 더 크다는 것을 보인 바 있다. 이러한 신용등급과 재무변수에 대한 국내연구의 시발점은

5) 그리고 이러한 등급변동의 자기암시(self-fulfilling) 기능으로 인해 신용등급이 하향될 경우 해당 기업의 영업활동은 더욱 위축되고 이 결과 신용등급이 다시금 하락하는 악순환이 존재한다.

6) 11 개 변수는 총자산경상이익률, 총자산경상이익률의 변화, 총자산대비영업현금흐름비율, 영업현금 흐름과 경상이익의 차이, 레버리지 변화, 유동비율의 변화, 유상증자여부, 매출액영업이익률의 변화, 자산회전율의 변화, 이자보상배율, 자산규모의 변화 등이다. 
한국증권학회지 제49권 6호 (2020)

Altman(1968)의 Z-score연구이다. Altman(1968)은 5가지 재무비율7)을 사용하여 부도 발생 여부를 상당히 정확하게 예측할 수 있음을 보였다. Altman and Rijiken(2004)는 부도예측 모형과 신평사 신용등급 예측 모형을 비교·분석하면서, 신평사의 신용등급이 부도예측 모형보다 경기일관적인 특성이 있음도 보였다.

둘째, 신용등급의 변경에 대한 연구들이다. Kim and Yoon(2013)은 신용등급의 변경 가능성이 자본구조에 미치는 영향을 연구하였다. 이들은 $(+)$ 노치를 등급상향 가능성, $(-)$ 노치를 등급하향 가능성으로 정의하고, $( \pm)$ 노치가 기업의 자본구조 미치는 영향에 대해 분석하였다. 부채비율을 종속변수로 두고 실증분석한 결과, $(+),(-)$ 노치 모두 유의한 음의 값을 보여 전기(t-1)의 등급조정 가능성이 당기(t) 부채비율을 유의하게 낮춘다는 것을 보였다. 등급별로는 $\mathrm{A}$ 와 $\mathrm{BBB}$ 등급에서 등급변경 가능 더미변수의 계수가 유의한 것으로 나타났다.8) Jung and Park(2017)는 신용등급의 변경을 초래하는 원인을 분석하였다. 복수평가제도 하에서 발행자의 신평사 변경 여부가 다음 기 회사채 등급 변경에 미치는 영향에 분석의 주안점을 두었다. 차기 등급 상승 여부를 종속변수로 설정한 로짓분석, 그리고 등급변동의 정도를 종속변수로 설정한 순서형 프로빗 분석을 통해 발행자의 신평사 변경이 유의한 영향력을 끼친다는 것을 밝혔다. 후속 연구에서 Jung and $\operatorname{Park}(2018)$ 는 회사채의 수익률 스프레드를 종속변수로 삼고, 신평사 간 평가등급 차이 여부를 설명변수로 설정할 경우 동 변수의 계수가 유의한 양 $(+)$ 의 값을 갖는다는 것도 보였다. 즉 신평사 간 평가등급이 차이가 발생할 경우, 신용등급에 대한 투자자들의 불확실성이 커지게 되어 회사채 스프레드가 상승한다는 것이다.

셋째, 신용등급의 상향편의 현상, 즉 등급인플레이션에 관한 연구들이다. $\mathrm{YeO}(2012)$ 은 2006 2011년의 기간 동안 상장된 기업의 $\mathrm{ROE}$ 와 부채비율, 신용등급간의 관계를 살펴본 결과 부채비율이나 $\mathrm{ROE}$ 악화에도 불구하고 회사채 투자등급의 비중이 상승하였다고 한다. 이 발견을 근거로 등급인플레이션 가능성을 지적하였다. Kim and $\mathrm{Kim}(2014)$ 은 신용등급에 영향을 미치는 부채비율, 매출액증가율, 이자보상비율 등을 통제한 상태에서 연도 변수의 계수 값이 증가하는 보임으로써 매년 신용등급이 상향(고평가)된다는 것을 보였다.9)

以上의 3가지 연구들은 신평사의 고유한 평가등급인 $\mathrm{AR}$ 을 대상으로 한 연구들이다. 그러나 $\mathrm{AR}$ 등급의 정확성에 대한 의구심을 제기할 만한 사건들이 발생하면서 $\mathrm{AR}$ 등급의 부정확성에 대한 판단지표로 부상한 채권내재등급(이하 BIR로 표기)에 대한 국내에서의 학술연구가 2010년 이후 진행되기 시작한다. $\mathrm{BIR}$ 등급은 채권의 유통수익률에 근거해 $\mathrm{AR}$ 과 같은 기호를 사용하여 신용등급을 산정한 것으로 시장내재등급(MIR)의 하나이다. 해외에서 시장내재등급(Market

7) 사용된 재무비율 변수는 다음과 같다. 운전자본/총자산, 이익잉여금/총자산, 영업이익/총자산, 시가 총액/총부채, 매출액/총자산이다.

8) 그 배경으로는 $\mathrm{A}$ 등급의 경우 기업 경영의 호재로 부채비율을 낮추고 $\mathrm{BBB}$ 등급의 경우에는 투기등급 으로의 하락을 막기 위한 자본구조 개선 노력에 기인한 것이라고 분석하였다.

9) 구체적으로 이러한 등급 상향추세는 투자등급 채권에서는 목격되었지만, 투기등급에서는 나타나지 않았다고 명시하였다. 
Implied Rating, MIR) 산출에 사용되는 시장지수에는 주가, $\mathrm{CDS}$, 채권수익률(스프레드) 등이 있다.10) 이러한 시장내재등급(Market Implied Rating: MIR)은 2000년 엔론사태를 계기로 신평사 등급에 대한 의존도를 축소시키기 위해 활용되기 시작하였고 현재는 3대 글로벌 신평사인 Moody's, S\&P, Fitch 모두 시장내재등급(MIR)을 사용하고 있다. 국내에서는 한국신평사가 2006년 KIS 채권평가가 제공하는 일별 시장수익률을 활용하여 채권내재등급(BIR)을 개발하였고, 나이스신용평가도 나이스피앤아이를 활용하여 채권내재등급(BIR)을 개발하여 보조자료로 활용하고 있다. 참고로 Moody's는 BIR을 주로 활용하고, S\&P는 CDS를 활용한 시장내재등급 (MDS)을 많이 사용하는 것으로 알려져 있다.11) 한편 $\mathrm{BIR}$ 은 $\mathrm{AR}$ 과 달리 채권의 수요와 공급, 금융시장의 계절적 변동, 경기동향 등 다양한 요인에 의해 영향을 받아 결정되는 유통수익률을 기반으로 하기 때문에 상대적으로 변동성이 높지만, 시장의 정보를 적시(Accuracy)에 전달한다는 점에서 강점을 지녔다. 이 점은 안정성을 중시하는 $\mathrm{AR}$ 과 차별되는 속성이다.

이런 배경에서 진행된 네 번째 연구들은 BIR등급과 관련된 연구이다. Kang and Han(2013)의 연구가 시발점이다. 이들은 $\mathrm{AR}$ 과 $\mathrm{BIR}$ 등급 간 비교를 통해 등급인플레이션 현상의 존재 여부를 보였다. 업종별로는 어업, 건설업, 금융보험업 및 부동산 임대업에서, 기업집단별로는 자산규모 26-50위 군에서 등급인플레이션 가능성이 존재한다고 밝혔다.12) Kang et al.(2015)은 후속 연구에서 $\mathrm{AR}$ 과 $\mathrm{BIR}$ 등급을 비교하는 방식으로 회사채 발행 비중이 큰 고객군에서 등급인플 레이션이 존재함을 밝혔다. Oh and Chung(2015)는 AR과 BIR의 두 가지 속성인 안정성과

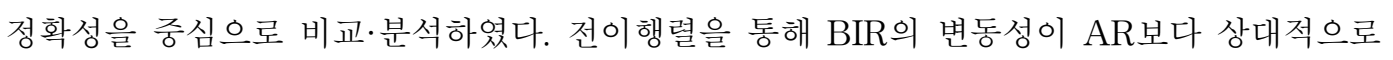
높다는 것을 보였다. 그리고 양 신용등급 모두 경기정점(peak)에서 등급 변동성이 적지만,

10) 먼저 주가를 기반으로 한 연구에는 Löffler(2007)이 있다. 동 연구는 KMV(Kealhofer, McQuown, and Vasicek)방법을 활용하여 주가에 기반한 $\mathrm{EDF}$ 를 도출하고, 이에 따라 신용등급을 산출하였다. Tsoukas and Spaliara(2014)는 CDS를 기반으로 부도위험과 신용등급을 산정하고, 부채비율, 이자보상비율, 유동성비율 등 재무정보와 재무적 제약이 同 신용등급과 연관성이 높음을 밝혔다. 마지막으로 채권스프레드를 기반으로 한 연구들이다. 시기별로 정리하면 Breger et al.(2003)는 신용평가기관이 평가한 $\mathrm{AR}$ 등급과 채권금리 스프레드를 기반으로 산출된 내재등급(SIR: Spread Implied Rating)간 부도 예측력을 비교하면서 SIR등급이 AR등급에 비해 2 3개월 앞서 부도를 예측하고 있음을 확인하였다. 이후 Longstaff et al.(2005)는 회사채의 스프레드중 유동성 스프레드를 제외한 나머지 부분이 기업의 부도확률이 설명하고 있으며, 투기등급(BBB)에 대해서는 부도 설명력이 $84 \%$ 에 달함을 보였다. Kou and Varotto(2008)는 SIR등급이 최대 6개월까지 선행하여 AR등급 예측에 유의함을 밝혔다. 그리고 이러한 SIR 또는 BIR(Bond Implied Rating)은 글로벌 신용평가사인 무디스에서 실무적으로 사용되기 시작하였다.

11) 이에 대한 내용은 Moody's Credit Strategy Group의 Moody's Market Implied Ratings Description, Methodology, and Analytical Applications(Munves et al., 2007)과 Standard \& Poor's 의 How Standard \& Poor's Arrives At Market Derived Signals(Bergman et al., 2009)을 참고하였다.

12) Kang and $\operatorname{Han}(2013)$ 은 $\mathrm{AR}$ 이 $\mathrm{BIR}$ 보다 2등급 이상 높은 것의 비중(21.9\%)이 $\mathrm{AR}$ 이 $\mathrm{BIR}$ 보다 낮은 것의 비중 $(3.8 \%)$ 보다 5 배를 상회하는 것을 보고 등급인플레이션 문제를 제기하고 t-test를 통해 등급인플레이션 존재를 확인하였다, 또한 회사채유통 수익률을 종속변수로, 설명변수로 $\mathrm{AR}$ 과 $\mathrm{BIR}$ 을 설정하고 통제변수로 국고채 수익률, 부채자산비율, 자산액(로그값), 매출액(로그값), 종합주가지수 수익률 및 그 변동성을 사용한 분석에서 $\mathrm{AR}$ 에 비해 $\mathrm{BIR}$ 의 설명력이 높다고 주장한다. 
한국증권학회지 제49권 6호 (2020)

경기저점(trough)에서는 등급하향이 많아지는 현상을 지적하였다.13) 그리고 부도예측력에서는 $\mathrm{BIR}$ 이 좀 더 정확하지만, $\mathrm{AR}$ 과 $\mathrm{BIR}$ 은 상호 보완적으로 사용될 수 있다고 주장하였다. 이후 $\mathrm{Ahn}$ et al.(2016)는 재무변수와 BIR등급 간에 대한 분석을 최초로 시도한다. 이들의 연구에서 $\mathrm{BIR}$ 등급은 재무변수와 유의한 연관성을 보이고, 그 방향성은 기존 $\mathrm{AR}$ 등급과 유사하다는 것을 밝혔다.14) $\mathrm{AR}$ 을 종속변수로 할 경우 유동성, 현금창출능력, 기업규모, 매출액변동성이 유의한 설명력을 보였고, $\mathrm{BIR}$ 을 종속변수로 할 경우 수익성, 영업이익률의 변동성이 유의한 설명력을 가진다는 것을 밝혔다. 그 결과 $\mathrm{BIR}$ 등급은 $\mathrm{AR}$ 등급의 미비점을 보완하면서 정보의 적시성을 제고할 수 있다고 한다. Ahn et al.(2018)은 후속연구에서 AR과 BIR간 등급의 불일치가 차기 신용등급의 변경 가능성, 그리고 자본조달에 미치는 영향을 분석하였다.15) 참고로 동 연구는 패널 프로빗 분석으로 이루어졌다.

본 고는 4 번째 연구류 중 하나이다. 구체적으로는 시장상황을 대변하는 거시경제변수와 기업의 재무변수들이 신용등급 $(\mathrm{AR})$ 과 채권내재등급 $(\mathrm{BIR})$ 에 미치는 영향을 분석한다. 패널분석을 통해 기업의 고유한 특성을 통제한 상태에서 설명변수들이 신용등급에 미치는 영향을 순서형 로짓 모형으로 분석하였다. 또한 재무변수 등의 설명변수가 AR과 BIR등급에 각각 미치는 민감도 차이가 있다는 점에 착안하여 양 신용등급간 불일치(BIR-AR), 등급인플레이션(내지 등급디플 레이션) 발생 원인도 설명변수를 통해 분석하였다. 이 계기는 Oh and Chung(2015)가 지적한 것처럼 $\mathrm{AR}$ 과 $\mathrm{BIR}$ 등급은 도출원리상의 차이 때문에 불일치발생이 불가피하다는 점에 착안 하였다. 실제 BIR은 시장의 유동성 상황, 경기하강기에 따른 수익률 스프레드의 상승, 그리고 기업의 시장지위, 영업환경 변화를 $\mathrm{AR}$ 과 달리 민감하게 반영하는 속성을 지니기 때문에 등급불일치가 발생할 수밖에 없을 것이다. 한편 BIR에 대한 패널분석 은 Ahn et al.(2018)에서 최초로 시도한 바 있다. 하지만 등급불일치를 차기 등급변경의 원인변수로 설정한데 반해, 본 고는 등급불일치를 결과변수로 설정하고, 등급불일치가 발생한 원인을 기업의 재무상태나 거시경제변수(유동성, 수출, 산업활동지수)로 조명한다는 점에서 서로 다른 연구이다. 그리고 $\mathrm{AR}$ 과 $\mathrm{BIR}$ 등급에 대한 이들 설명변수의 민감도 차이를 등급불일치의 원인으로 연구한 것으로는 본 고가 최초이다.

13) 특히 $\mathrm{BBB}$ 등급의 경우 경기정점에서는 등급 상향, 경기 저점에서는 등급하향 추세가 여타 등급에 비해 가장 뚜렷하게 나타났다.

14) 구체적으로는 신용등급을 종속변수로 순서형 프로빗 분석을 실시하였으며 기업의 재무적 제약 여부와 등급판정간의 관계도 분석하였다.

15) 전기 $(\mathrm{t}-1)$ 에 $\mathrm{BIR}$ 이 $\mathrm{AR}$ 보다 높을 경우, 다음 기 $(\mathrm{t})$ 등급 상향이 발생함을 확인하였다. 또한 등급하락이 예상되는 경우(BIR이 $\mathrm{AR}$ 보다 낮은 경우)에는 순부채를 줄이지만 등급 상승이 예상되는 경우(BIR이 $\mathrm{AR}$ 보다 높은 경우)에는 부채조달을 하지 않는다는 비대칭적인 구조도 확인하였다. 이러한 연구들은 Kisgen(2006)의 연장선으로 보인다. Kisgen(2006)은 신용등급이 자본구조 결정에 유의한 영향을 미친다는 CR-CS(Credit Ratings-Capital Structures) 가설을 제시였는데, 요지는 기업들이 보다 유리한 신용등급을 받기 위해 자본구조를 변경시킨다는 내용이다. 


\section{3. 연구방법론}

\section{1 표본}

분석에 사용된 데이터는 2009.1분기부터 2019.3분기까지(시계열 43개 분기)의 11년간 자료이다. 신용등급은 2009 2019년 중 나이스신용평가가 산정한 신용등급(AR)과 나이스피앤 아이가 산출한 채권내재등급(BIR)자료를 사용하였고 분석 대상기업에 대한 재무제표 정보는 KIS-VALUE에서 추출하였다. 신용등급이 있는 기업 중 재무자료를 확보할 수 없는 비상장기업과 은행, 보험, 증권업의 금융업을 제외하였더니 총 3,035 개(240개 기업)의 표본이 최종 분석 대상이 되었다.

아래의 <표 $1>$ 은 $\mathrm{AR}$ 등급을 기준으로 재무변수들의 평균값을 정리한 것이다. 분석에 사용된 재무변수들은 기업 규모( $\log$ 자산), 유동자산비율(유동자산/자산), 부채비율(부채/자산)과 수익성 지표인 매출비율(매출/자산), $\mathrm{EBIT}(\mathrm{EBIT} /$ 자산), 당기순이익(당기순이익/자산), $\mathrm{OCF}(\mathrm{OCF} /$ 자산), 감가상각비율(감가상각비(무형자산상각비포함)/자산)이다. 또한 변동성측정 지표로는 매출액 표준편차(직전 3 분기를 포함한 4 분기의 매출액 표준편차, 단위: 조원), 영업이익표준편차(같은 방식으로 영업이익의 표준편차, 단위: 조원)를 산출하여 이용하였다.

\section{〈표 1〉 AR의 각 평균}

(전체 표본, 단위: $\%$, 표준편차는 단위: 조원)

\begin{tabular}{|c|c|c|c|c|c|c|c|c|c|c|c|}
\hline \multirow[b]{2}{*}{$\mathrm{AR}$} & \multirow[b]{2}{*}{ BIR } & \multirow[b]{2}{*}{ 자산 } & \multirow[b]{2}{*}{$\begin{array}{l}\text { 유동 } \\
\text { 자산 }\end{array}$} & \multirow[b]{2}{*}{ 부채 } & \multirow[b]{2}{*}{ 매출액 } & \multirow[b]{2}{*}{ EBIT } & \multirow[b]{2}{*}{$\begin{array}{c}\text { 당기 } \\
\text { 순이익 }\end{array}$} & \multirow[b]{2}{*}{$\mathrm{OCF}$} & \multirow[b]{2}{*}{$\begin{array}{c}\text { 감가 } \\
\text { 상각비 }\end{array}$} & \multicolumn{2}{|c|}{ 표준편차 } \\
\hline & & & & & & & & & & 매출액 & $\begin{array}{l}\text { 영업 } \\
\text { 이익 }\end{array}$ \\
\hline $\mathrm{AAA}(0)$ & 0.019 & 13.489 & 0.2060 & 0.4937 & 0.1648 & 0.0107 & 0.0084 & 0.0230 & 0.0158 & 7.055 & 3.619 \\
\hline $\mathrm{AA}+(1)$ & 0.777 & 13.046 & 0.2969 & 0.4337 & 0.2431 & 0.0148 & 0.0112 & 0.0184 & 0.0065 & 3.638 & 1.168 \\
\hline $\mathrm{AA}(2)$ & 1.546 & 12.717 & 0.2997 & 0.4304 & 0.2152 & 0.0133 & 0.0107 & 0.0210 & 0.0087 & 2.052 & 0.771 \\
\hline $\mathrm{AA}-(3)$ & 2.629 & 12.531 & 0.3823 & 0.4915 & 0.2599 & 0.0097 & 0.0103 & 0.0203 & 0.0092 & 1.678 & 0.407 \\
\hline$A+(4)$ & 4.162 & 12.284 & 0.3744 & 0.4928 & 0.2063 & 0.0088 & 0.0075 & 0.0178 & 0.0087 & 1.141 & 0.288 \\
\hline A(5) & 5.453 & 12.307 & 0.3925 & 0.5613 & 0.2342 & 0.0041 & 0.0034 & 0.0125 & 0.0065 & 0.878 & 0.246 \\
\hline A-(6) & 6.275 & 12.083 & 0.3717 & 0.5460 & 0.2171 & 0.0044 & 0.0034 & 0.0100 & 0.0090 & 0.438 & 0.143 \\
\hline $\mathrm{BBB}+(7)$ & 7.437 & 12.145 & 0.3989 & 0.6318 & 0.2094 & -0.006 & -0.006 & 0.0077 & 0.0094 & 0.583 & 0.294 \\
\hline BBB(8) & 8.423 & 12.098 & 0.3595 & 0.6265 & 0.1826 & -0.006 & -0.006 & 0.0083 & 0.0042 & 0.457 & 0.212 \\
\hline BBB-(9) & 8.759 & 11.870 & 0.3718 & 0.6246 & 0.1619 & -0.006 & -0.005 & 0.0157 & 0.0176 & 0.305 & 0.125 \\
\hline BB(11) & 6.000 & 12.089 & 0.7555 & 0.8364 & 0.9453 & 0.0109 & 0.0088 & -0.004 & 0.0004 & 1.605 & 0.033 \\
\hline D(17) & 9.000 & 12.398 & 0.1124 & 0.9200 & 0.0988 & -0.115 & -0.115 & -0.001 & 0.0102 & 1.45 & 1.033 \\
\hline
\end{tabular}

먼저 자산으로 측정된 기업의 규모는 상위 신용등급일수록 크다는 것을 알 수 있다. 반면에 유동자산 비율은 상위 신용등급에서 오히려 낮다. 유동자산 비율은 현금화 지표인데, 동 비율이 높을수록 부채 지불(상환) 능력이 좋다고 볼 수도 있지만, 반대로 高 유동자산 비율은 자산의 비효율적인 사용으로 해석할 여지도 있다. 상위 신용등급에서 유동자산 비율이 낮은 것은, 자산의 비효율적 사용 가능성이 축소된 것으로 볼 수 있겠다. 수익성 지표에서 당기순이익 등 다른 
한국증권학회지 제49권 6호 (2020)

변수들은 일관된 패턴을 찾기 어려웠던 반면에, EBIT비율은 신용 등급이 양호한 곳에서 상대적으로 높았다. EBIT비율이 높을수록 신용등급이 양호해진다고 볼 수 있겠다. 한편 $\mathrm{AAA}$ 등급에서는 감가상각비율이 상대적으로 크게 나타났다. 감가상각비는 비현금성 비용으로 수익과 비용 대응 원칙에 따라 설비자산이 클수록 감가상각비가 높을 수 있는데, 자산의 규모가 큰 $\mathrm{AAA}$ 등급에서 감가상각비율은 큰 것으로 나타났다. 또한 수익성지표의 표준편차는 통상 미래 예측 시 변동성을 나타내는 지표로 변동성의 확대는 미래 수익의 불확실성의 증가로 해석할 수 있다. AAA등급의 경우 표준편차가 상대적으로 매우 높은 값을 보이는데 이는 성숙기업의 안정적이고 높은 매출액 수준으에 의한 결과라고 해석할 수 있다. 또한 변동성이 성장 기업인 경우 매출액이 커지면서 표준편차가 확대될 수 있기 때문에 긍정적인 요소로 해석할 여지도 존재하므로 전반적인 기업 업황과 경기상황을 고려하여 해석할 필요가 있다.

〈표 2〉AR과 등급분포

\begin{tabular}{lrrrr}
\hline \multicolumn{1}{c}{$\mathrm{AR}$ 등급 } & $\mathrm{AR}<\mathrm{BIR}$ & $\mathrm{AR}=\mathrm{BIR}$ & $\mathrm{AR}>\mathrm{BIR}$ & \multicolumn{1}{c}{ 전체 } \\
\hline $\mathrm{AAA}(0)$ & $2(1.9 \%)$ & $105(98.1 \%)$ & $0(0.0 \%)$ & $107(100 \%)$ \\
$\mathrm{AA}+(1)$ & $24(8.5 \%)$ & $157(55.5 \%)$ & $102(36.0 \%)$ & $283(100 \%)$ \\
$\mathrm{AA}(2)$ & $33(10.6 \%)$ & $140(44.7 \%)$ & $140(44.7 \%)$ & $313(100 \%)$ \\
$\mathrm{AA}-(3)$ & $108(20.9 \%)$ & $136(26.3 \%)$ & $273(52.8 \%)$ & $517(100 \%)$ \\
$\mathrm{A}+(4)$ & $117(23.4 \%)$ & $314(62.8 \%)$ & $69(13.8 \%)$ & $500(100 \%)$ \\
$\mathrm{A}(5)$ & $233(47.9 \%)$ & $150(30.9 \%)$ & $103(21.2 \%)$ & $486(100 \%)$ \\
$\mathrm{A}-(6)$ & $199(40.9 \%)$ & $194(39.8 \%)$ & $94(19.3 \%)$ & $487(100 \%)$ \\
$\mathrm{BBB}+(7)$ & $97(45.5 \%)$ & $97(45.5 \%)$ & $19(9.0 \%)$ & $213(100 \%)$ \\
$\mathrm{BBB}(8)$ & $55(56.7 \%)$ & $28(28.9 \%)$ & $14(14.4 \%)$ & $97(100 \%)$ \\
$\mathrm{BBB}-(9)$ & $0(0.0 \%)$ & $24(82.8 \%)$ & $5(17.2 \%)$ & $29(100 \%)$ \\
$\mathrm{BB}(11)$ & $0(0.0 \%)$ & $0(0.0 \%)$ & $2(100.0 \%)$ & $2(100 \%)$ \\
$\mathrm{D}(17)$ & $0(0.0 \%)$ & $0(0.0 \%)$ & $1(100.0 \%)$ & $1(100 \%)$ \\
\hline 전체 & $868(28.6 \%)$ & $1,345(44.3 \%)$ & $822(27.1 \%)$ & $3,035(100 \%)$ \\
\hline
\end{tabular}

<표 2>에서는 $\mathrm{AR}$ 등급에 대한 $\mathrm{BIR}$ 의 분포를 살펴본다. 부등호는 각 등급에 해당하는 숫자의 크고 작음을 의미한다. 순서형 로짓 분석을 위해 문자인 신용등급을 숫자화하는 작업이 필요한데, 본고에서는 상위 신용등급일수록 숫자가 작아지는 방식으로 코딩하였다. 즉 $\mathrm{AAA}$ 등급은 0 을, $\mathrm{AA}+$ 등급에는 1 의 숫자를 부여하였다. 이 방식에 따르면 등급불일치인 $\mathrm{AR}>\mathrm{BIR}$ 은 $\mathrm{AR}$ 보다 $\mathrm{BIR}$ 의 등급이 더 좋은 것으로 등급디플레이션을 의미한다.

한편 $\mathrm{BR}$ 은 시장가격을 반영한 신용등급이기 때문에 회사채의 시장수익률 변동에 따라 비교적 잦은 등급 변동을 보이는 반면에 $\mathrm{AR}$ 은 신용평가사의 보수적인 평가방식 때문에 등급 변동이 상대적으로 보수적인 것으로 알려져 있는데, 이는 아래의 <표 $3>$ 에서도 확인해볼 수 있다. 연구에 사용된 240개 기업에 대해 표본의 전 구간에 대해 정리한, $\mathrm{AR}$ 등급과 $\mathrm{BIR}$ 등급의 표준편차의 사분위수 분포는 아래와 같다. 중간 값을 기준으로 할 때 $\mathrm{AR}$ 은 $0.452, \mathrm{BIR}$ 은 0.740 으로 나타나고 있다. 
〈표 3〉각 등급에 대한 표준편차

\begin{tabular}{lrr}
\hline & AR & BIR \\
\hline 평균 & 0.43246 & 0.70544 \\
1st Qu. & 0 & 0.27735 \\
median & 0.45241 & 0.74001 \\
3st Qu. & 0.6513389 & 1.02026 \\
Max & 5 & 2.49666 \\
\hline
\end{tabular}

앞의 <표 2>에서 전체 표본 중 $\mathrm{AR}$ 이 $\mathrm{BIR}$ 등급보다 좋은 표본의 개수는 868 개(28.6\%), $\mathrm{BIR}$ 등급보다 나쁜 표본의 개수는 822 개(27.1\%)로 대략 대칭적인 구조이다. 하지만 개별 등급별로 살펴보면, $\mathrm{AA}$ 이상의 신용등급에서는 대체로 $\mathrm{BIR}$ 신용등급이 더 양호한 비중이 두 배를 넘은 반면에, $\mathrm{A}$ 이하 $\mathrm{BBB}$ 까지 신용등급 구간에서는 $\mathrm{BIR}$ 신용등급이 더 나쁜 표본의 비중이 많다. 따라서 상위 신용등급인 경우 시장에서의 평가(BIR)가 신평사(AR)보다 후한 것으로 판단된다. 투기등급인 $\mathrm{BB}$ 와 $\mathrm{D}$ 등급인 경우도 마찬가지로 시장의 평가가 신평사보다 좋은 것으로 나타났지만, 표본의 수가 적어 대표성을 갖는다고 보기는 어렵다.

전체 표본(총 3,035개)중 44.3\%(1,345개의 표본)에서 $\mathrm{AR}$ 과 $\mathrm{BIR}$ 이 일치하지만, 과반수의 표본에서는 두 등급이 서로 차이를 보이고 있다. 이러한 $\mathrm{AR}$ 과 $\mathrm{BIR}$ 두 등급 간의 불일치 발생 요인들을 기존 연구들이 제기한 이슈와 관련해 점검하고자, 아래에서는 대기업여부, 업종별 그리고 경기구간(경기하강기 여부)으로 구분해서 살펴본다.

〈표 4〉대기업 소속 여부에 따른 등급분포

\begin{tabular}{lcccrrr}
\hline \multicolumn{1}{c}{ 집단 구분 } & $\mathrm{AR}$ & $\mathrm{BIR}$ & $\mathrm{AR}<\mathrm{BIR}$ & $\mathrm{AR}=\mathrm{BIR}$ & $\mathrm{AR}>\mathrm{BIR}$ & \multicolumn{1}{c}{ 전체 } \\
\hline 0(not big) & 5.09 & 5.06 & $281(28.9 \%)$ & $418(43.0 \%)$ & $274(28.2 \%)$ & $973(100.0 \%)$ \\
1(big) & 3.60 & 3.69 & $587(28.5 \%)$ & $927(45.0 \%)$ & $548(26.6 \%)$ & $2,062(100.0 \%)$ \\
\hline 전체 & 4.35 & 4.38 & $868(28.6 \%)$ & $1,345(44.3 \%)$ & $822(27.1 \%)$ & $3,035(100.0 \%)$ \\
\hline
\end{tabular}

먼저 기업집단 구분에 따른 등급불일치 여부를 살펴보기 위해 <표 $4>$ 와 같이 자료를 정리 하였다. 공정거래위원회의 상호출자제한기업집단 및 출자총액제한집단 발표 자료를 사용하여 해당 분류에 속하는 기업을 대기업 집단(BIG)으로 분류하였다. 대기업 집단 내에서 살펴보면 $\mathrm{AR}$ 이 $\mathrm{BIR}$ 보다 높거나, 낮은 등급의 비중이 비슷한 상태이다. 다만 대기업(BIG)인 경우 $\mathrm{AR}$ 과 $\mathrm{BIR}$ 등급 모두 높게 나타나고 있다. 대기업(BIG)의 평균 $\mathrm{AR}$ 은 $\mathrm{AA}-(3)$ 와 $\mathrm{A}+(4)$ 구간에 분포하고 있는 반면에, 대기업이 아닌 경우 $(\mathrm{BIG}=0)$ 평균 $\mathrm{AR}$ 은 $\mathrm{A}(5)$ 로 신용등급 체계상 두 단계 정도 낮은 수준이며, BIR도 비슷한 양상을 보이고 있다. 본 연구는 대기업인 경우 $\mathrm{AR}$ 등급판정이 유리해지는지, 소위 등급인플레이션이 있는지를 $\mathrm{BIR}$ 등급과 비교해 본다. 그리고 만약에 등급인플레이션이 존재한다면 그 원인은 어떤 것인지를 재무변수별로 분석을 시도해 본다. 
한국증권학회지 제49권 6호 (2020)

다음은 업종별로 신용등급 불일치 분포를 아래의 <표 5>와 같이 정리해보았다. 업종구분은 통계청의 한국표준산업분류(제 10 차)를 사용하였다. 한국표준산업분류는 그동안 9 차례에 개정 되었는데 본 연구에서는 2017년도에 시행된 10차 분류를 따랐다. <표 $4>$ 에서 $\mathrm{AR}<\mathrm{BIR}$ 의 비중이 특히 높고(33\% 이상), 두 신용등급간의 차이가 뚜렷한 건설(40), 운수 및 창고(49), 전문 과학 및 기술서비스업(70)에서는 등급인플레이션이 의심된다.16) 본 연구는 이들 업종에 대해 등급인플레이션을 여부를 확인하기 위해 더미변수를 이용해 추가로 분석한다.

\section{〈표 5〉업종별 등급분포}

\begin{tabular}{|c|c|c|c|c|c|c|}
\hline 업종대분류 & $\mathrm{AR}$ & $\mathrm{BIR}$ & $\mathrm{AR}<\mathrm{BIR}$ & $\mathrm{AR}=\mathrm{BIR}$ & $\mathrm{AR}>\mathrm{BIR}$ & 전체 \\
\hline 1(농업, 임업, 및 어업) & 3.83 & 4.17 & $\begin{array}{r}6 \\
(33.3 \%)\end{array}$ & $\begin{array}{r}10 \\
(55.6 \%)\end{array}$ & $\begin{array}{r}2 \\
(11.1 \%)\end{array}$ & $\begin{array}{r}18 \\
(100.0 \%)\end{array}$ \\
\hline 10(제조업) & 4.20 & 4.08 & $\begin{array}{r}338 \\
(21.4 \%)\end{array}$ & $\begin{array}{r}769 \\
(48.7 \%)\end{array}$ & $\begin{array}{r}473 \\
(29.9 \%)\end{array}$ & $\begin{array}{r}1,580 \\
(100.0 \%)\end{array}$ \\
\hline $\begin{array}{l}\text { 35(전기, 가스, 증기 조절 } \\
\text { 공급업) }\end{array}$ & 1.49 & 1.42 & $\begin{array}{r}6 \\
(7.0 \%)\end{array}$ & $\begin{array}{r}69 \\
(80.2 \%)\end{array}$ & $\begin{array}{r}11 \\
(12.8 \%)\end{array}$ & $\begin{array}{r}86 \\
(100.0 \%)\end{array}$ \\
\hline 41(건설업) & 5.30 & 6.91 & $\begin{array}{r}275 \\
(93.5 \%)\end{array}$ & $\begin{array}{r}19 \\
(6.5 \%)\end{array}$ & $\begin{array}{r}0 \\
(0.0 \%)\end{array}$ & $\begin{array}{r}294 \\
(100.0 \%)\end{array}$ \\
\hline 45(도매 및 소매업) & 3.30 & 3.00 & $\begin{array}{r}56 \\
(18.0 \%)\end{array}$ & $\begin{array}{r}129 \\
(41.5 \%)\end{array}$ & $\begin{array}{r}126 \\
(40.5 \%)\end{array}$ & $\begin{array}{r}311 \\
(100.0 \%)\end{array}$ \\
\hline 49(운수 및 창고업) & 6.09 & 6.48 & $\begin{array}{r}52 \\
(43.3 \%)\end{array}$ & $\begin{array}{r}52 \\
(43.3 \%)\end{array}$ & $\begin{array}{r}16 \\
(13.3 \%)\end{array}$ & $\begin{array}{r}120 \\
(100.0 \%)\end{array}$ \\
\hline 55(숙박) & 2.90 & 2.80 & $\begin{array}{r}4 \\
(13.3 \%)\end{array}$ & $\begin{array}{r}19 \\
(63.3 \%)\end{array}$ & $\begin{array}{r}7 \\
(23.3 \%)\end{array}$ & $\begin{array}{r}30 \\
(100.0 \%)\end{array}$ \\
\hline 58(정보통신업) & 2.93 & 2.51 & $\begin{array}{r}25 \\
(10.5 \%)\end{array}$ & $\begin{array}{r}121 \\
(51.1 \%)\end{array}$ & $\begin{array}{r}91 \\
(38.4 \%)\end{array}$ & $\begin{array}{r}237 \\
(100.0 \%)\end{array}$ \\
\hline 64(금융) & 3.71 & 3.64 & $\begin{array}{r}64 \\
(23.7 \%)\end{array}$ & $\begin{array}{r}119 \\
(44.1 \%)\end{array}$ & $\begin{array}{r}87 \\
(32.2 \%)\end{array}$ & $\begin{array}{r}270 \\
(100.0 \%)\end{array}$ \\
\hline $\begin{array}{l}\text { 70(전문, 과학 및 기술 } \\
\quad \text { 서비스업) }\end{array}$ & 4.35 & 4.62 & $\begin{array}{r}23 \\
(44.2 \%)\end{array}$ & $\begin{array}{r}21 \\
(40.4 \%)\end{array}$ & $\begin{array}{r}8 \\
(15.4 \%)\end{array}$ & $\begin{array}{r}52 \\
(100.0 \%)\end{array}$ \\
\hline 74(사업시설관리) & 7.09 & 7.30 & $\begin{array}{r}6 \\
(26.1 \%)\end{array}$ & $\begin{array}{r}16 \\
(69.6 \%)\end{array}$ & $\begin{array}{r}1 \\
(4.3 \%)\end{array}$ & $\begin{array}{r}23 \\
(100.0 \%)\end{array}$ \\
\hline 85(교육서비스) & 6.14 & 7.00 & $\begin{array}{r}6 \\
(85.7 \%)\end{array}$ & $\begin{array}{r}1 \\
(14.3 \%)\end{array}$ & $\begin{array}{r}0 \\
(0.0 \%)\end{array}$ & $\begin{array}{r}7 \\
(100.0 \%)\end{array}$ \\
\hline $\begin{array}{l}\text { 90(예술, 스포츠 및 } \\
\quad \text { 여가관련 서비스업) }\end{array}$ & 3.00 & 4.20 & $\begin{array}{r}5 \\
(100.0 \%)\end{array}$ & $\begin{array}{r}0 \\
(0.0 \%)\end{array}$ & $\begin{array}{r}0 \\
(0.0 \%)\end{array}$ & $\begin{array}{r}5 \\
(100.0 \%)\end{array}$ \\
\hline $\begin{array}{l}\text { 94(협회 및 단체 수리 및 } \\
\text { 기타 개인 서비스업) }\end{array}$ & 4.00 & 5.50 & $\begin{array}{r}2 \\
(100.0 \%)\end{array}$ & $\begin{array}{r}0 \\
(0.0 \%) \\
\end{array}$ & $\begin{array}{r}0 \\
(0.0 \%) \\
\end{array}$ & $\begin{array}{r}2 \\
(100.0 \%)\end{array}$ \\
\hline 전체 & 4.35 & 4.38 & $\begin{array}{r}868 \\
(28.6 \%)\end{array}$ & $\begin{array}{r}1345 \\
(44.3 \%)\end{array}$ & $\begin{array}{r}822 \\
(27.1 \%)\end{array}$ & $\begin{array}{r}3,035 \\
(100.0 \%)\end{array}$ \\
\hline
\end{tabular}

16) 교육서비스(85), 예술, 스포츠 및 여가관련 서비스업(90), 예술, 스포츠 및 여가관련 서비스업(94) 또한 등급인플레이션이 의심되나 표본수가 적어 분석대상 업종에서 제외하였다. 
마지막으로 경기순환(경기하강기를 별도 구분)의 영향을 살펴보기 위해 자료기간 중 2011. 3 2013. 1분기와 2019. 1 3분기, 이상 두 구간을 경기 수축기17)로 정의하여 분석할 것이다. 먼저 <표 6>에서 연도별 평균 등급을 살펴보면 2009년 $\mathrm{BIR}$ 은 $\mathrm{A} \sim \mathrm{A}-$ 사이, $\mathrm{AR}$ 은 $\mathrm{A}+\sim \mathrm{A}$ 사이로 추정된다. 2019년 기준 $\mathrm{BIR}$ 의 평균등급(3.1)은 $\mathrm{AA}^{-}, \mathrm{AR}$ 의 평균등급(3.76)은 $\mathrm{A}+$ 에 가까운 모습을 보인다. $\mathrm{AR}$ 과 $\mathrm{BIR}$ 모두 전반적으로 등급이 상향되고 있음을 알 수 있다. 단순 평균등급의 분포만으로 경기하강기에 등급하향 현상을 확인할 수 없었다. 따라서 실증분석에서는 Oh and Chung(2015)의 연구에서 밝힌 것처럼 경기순환별 $\mathrm{AR}$ 과 $\mathrm{BIR}$ 의 속성차이, 그리고 경기저점에서 등급하향 현상이 나타나는지를 경기하강기 변수를 도입하여 별도로 검증할 것이다. 한편 2009 2012년 중 AR의 평균 등급은 BIR보다 높지만, 2013년 들어서 거의 비슷해지고, 2014 2019년 기간 중에는 역전되어 BIR의 평균등급이 AR보다 더 높아졌다. 이는 2009년 금융위기 이후 두 등급 모두 개선되었으나, 신평사 등급(AR)은 시장(BIR)보다 더 보수적인 것으로 보인다. 이는 Kang et al.(2015)에서 지적한 신평사 등급인플레이션 현상이 완화된 것으로 보이며 그러므로 본 고가 대상으로 하는 자료 후반기에는 등급인플레이션이 사라진 것으로 해석해 볼 여지가 있다. 그 원인으로는 2013년 동양증권 부실채권 판매, 2014년 STX, 대우조선해양의 분식회계 등의 여파로 보인다.

〈표 6〉연도별 등급 평균

\begin{tabular}{lccccccccccc}
\hline 연도 & 2009 & 2010 & 2011 & 2012 & 2013 & 2014 & 2015 & 2016 & 2017 & 2018 & 2019 \\
\hline $\mathrm{AR}$ & 4.82 & 4.54 & 4.39 & 4.18 & 4.12 & 3.97 & 3.78 & 3.82 & 3.81 & 3.76 & 3.76 \\
$\mathrm{BIR}$ & 5.42 & 5.05 & 4.82 & 4.33 & 4.14 & 3.87 & 3.67 & 3.83 & 3.74 & 3.37 & 3.10 \\
\hline
\end{tabular}

\section{2 연구 모형}

본 고는 $\mathrm{AR}$ 과 $\mathrm{BIR}$, 양 회사채 등급의 결정요인과 이들 변수의 민감도 차이를 분석한다. 이를 위해 회사채 신용등급과 해당 재무변수, 시장상황변수로 금리, 산업활동지수, 유동성 지표와 같은 거시경제변수에 대한 패널데이터를 구축하고, 이들 설명변수가 결정하는 회사채 신용등급을 종속변수로 하는 순서형 로짓 패널분석을 실시한다. 실증분석을 위해 신용등급은 $\mathrm{AAA}=0$, $\mathrm{AA}^{+}=1, \mathrm{AA}=2, \cdots$ 와 같은 방식으로 숫자화하였다. 실증분석에 사용된 순서형 로짓은 다음과 같은 방식으로 도출된다.

$$
y^{*}=\sum_{k=1}^{K} \beta_{k} x_{k}+\epsilon
$$

식 (1)에서 $y^{*}$ 는 관측되지 않는 신용위험 값으로 종속변수(response variable)이며, 관찰 가능한 신용등급 $(\mathrm{y})$ 의 범주는 $\mathrm{J}$ 개(AR 12 개, $\mathrm{BIR} 10$ 개)가 존재한다. $x_{k}$ 는 신용위험을 결정짓는

17) 통계청에 따르면 2008. 1 2009. 2월, 2011. 8 2013. 3월은 경기수축기로 정의하고 있다. 2019년의 경우 아직 통계청의 발표가 없었지만, 미중 무역 전쟁 등으로 2019 년의 경제성장률이 $2 \%$ 이하의 값을 보여 경기수축기로 간주하였다.

\section{6}


설명변수들이다. 동 설명변수로는 기업의 재무상태 변수, 시장상황을 나타내는 거시경제변수를 사용한다. 식 (2)는 관측되지 않는 $y^{*}$ 를 관측 가능한 신용등급의 범주 $\mathrm{j}$ 로 구분하는 기준을 나타낸다.

$$
\begin{array}{rlrl}
y^{*} & =1 & & \text { if } y^{*} \leq \mu_{1}(=0) \\
& =2 & & \text { if } \mu_{1}<y^{*}<\mu_{2} \\
\vdots & & \\
& =J & & \text { if } \mu_{J-1}<y^{*}
\end{array}
$$

식 (2)에서 $\mu$ 는 $y^{*}$ 의 경계값(threshold)으로 총 $\mathrm{J}$ 개의 관찰 가능한 범주에 각각 속할 기준이 된다. 순서형 로짓 모형은 $y^{*}$ 이 식 (2)의 구간에 속하는지 여부, 즉 $1,2, \cdots, J$ 에 속할 확률을 구하는 방식으로 설정된다. 누적분포함수(cumulative distribution function, $\mathrm{CDF}$ )와 식 (1)을 이용하면 $y$ 가 $j$ 에 속할 확률 값은 아래와 같이 도출될 수 있다.

$$
\begin{aligned}
\operatorname{Prob} .(y=j) & =\operatorname{Prob} .\left(\mu_{j-1}<y^{*}=\sum_{k=1}^{K} \beta_{k} x_{k}+\epsilon \leq \mu_{j}\right) \\
& =\operatorname{Prob} .\left(\mu_{j-1}-\sum_{k=1}^{K} \beta_{k} x_{k}<\epsilon \leq \mu_{j}-\sum_{k=1}^{K} \beta_{k} x_{k}\right) \\
& =F\left(\mu_{j}-\sum_{k=1}^{K} \beta_{k} x_{k}\right)-F\left(\mu_{j-1}-\sum_{k=1}^{K} \beta_{k} x_{k}\right)
\end{aligned}
$$

그리고 $y \leq j$ 인 확률은 아래와 같다.

$$
\operatorname{Prob} .(y \leq j \mid x)=F\left(\mu_{j}-\sum_{k=1}^{K} \beta_{k} x_{k}\right)=\frac{e^{\mu_{j}-\sum_{k=1}^{K} \beta_{k} x_{k}}}{1+e^{\mu_{j}-\sum_{k=1}^{K} \beta_{k} x_{k}}}
$$

식 (4)를 $\frac{P(y \leq j \mid x)}{1-P(y \leq j \mid x)}$ 로 변환한 뒤 로그값을 취하게 되면 아래와 같은 순서형 로짓모형의 Odds 로그값을 식 (6)과 같이 얻을 수 있다.

$$
\log \left[\frac{P(y \leq j \mid x)}{1-P(y \leq j \mid x)}\right]=\mu_{j}-\sum_{k=1}^{K} \beta_{k} x_{k}, j=1,2, \cdots, J-1
$$

참고로 Odds값은 (사건A가 발생할 확률)/(사건 A가 발생하지 않을 확률)인데 아래의 식 (6)으로 표현된다. 위의 식 (5)의 좌변에 exponential을 취한 것과도 같다.

$$
\text { Odds }=\frac{P(y \leq j)}{P(y>j)}
$$

참고로, 본 고에서는 좋은 신용등급에 적은 숫자를 부여하는 방식으로 코딩을 하였기에 아래와 같이 상기 Odds값의 역수를 사용한다는 점에서 차이가 있다. 


$$
\text { Odds }=\frac{P(y \geq j)}{P(y<j)}
$$

그리고 설명변수 한 단위 변화에 따른 Odds값의 한계(marginal)적 변화분은 오즈비(Odds Ratio)라고 하면 아래 식 (8)과 같이 정리된다.

$$
\frac{\exp \left(\alpha+\beta_{1} x_{1}+\cdots+\beta_{i}\left(x_{i}+1\right)+\cdots+\beta_{k} x_{k}\right)}{\exp \left(\alpha+\beta_{1} x_{1}+\cdots+\beta_{i} x_{i} \cdots+\beta_{k} x_{k}\right)}=\exp \left(\beta_{i}\right)
$$

식 (8)의 $\exp \left(\beta_{i}\right)$ 는 설명변수 $x_{i}$ 가 한 단위 증가할 때 오즈비를 나타낸다. 그리고 설명변수의 한계 증분이 종속변수인 신용등급에 미치는 효과는 아래와 같이 파악하게 된다.

$$
\begin{aligned}
\frac{\partial \operatorname{Pr} o b \cdot(y=j)}{\partial x_{k}} & =\frac{\partial}{\partial x_{k}}\left[F\left(\mu_{j}-\sum_{k=1}^{K} \beta_{k} x_{k}\right)-F\left(\mu_{j-1}-\sum_{k=1}^{K} \beta_{k} x_{k}\right)\right] \\
& =\left[f\left(\mu_{j-1}-\sum_{k=1}^{K} \beta_{k} x_{k}\right)-f\left(\mu_{j}-\sum_{k=1}^{K} \beta_{k} x_{k}\right)\right] \beta_{k} \\
& =\left[\frac{\exp \left(\mu_{j-1}-\sum_{k=1}^{K} \beta_{k} x_{k}\right)}{\left(1+\exp \left(\mu_{j-1}-\sum_{k=1}^{K} \beta_{k} x_{k}\right)\right)^{2}}-\frac{\exp \left(\mu_{j}-\sum_{k=1}^{K} \beta_{k} x_{k}\right)}{\left(1+\exp \left(\mu_{j}-\sum_{k=1}^{K} \beta_{k} x_{k}\right)\right)^{2}}\right] \beta_{k}
\end{aligned}
$$

추가적으로 설명변수가 $\mathrm{AR}$ 과 $\mathrm{BIR}$, 양 신용등급에 미치는 민감도 차이 분석을 위해 양 등급간 불일치 $(\mathrm{DIFF})$ 를 종속변수로 설정한 분석도 수행한다. 이를 위해 다음의 식 (10)과 같이 모형을 설정하였다.

$$
D I F F_{i, t}=\left\{\begin{array}{l}
1(B I R<A R) \\
2(B I R=A R) \\
3(B I R>A R)
\end{array}\right.
$$

본 고에서는 좋은 신용등급(AR, $\mathrm{BIR})$ 일수록 평점점수를 낮게 책정하였다. 따라서 등급불일치 변수인 $\mathrm{DIFF}$ 값이 1 인 것의 의미는 $\mathrm{AR}$ 등급이 $\mathrm{BIR}$ 등급보다 좋지 않다는 것을 의미한다. 즉 $\mathrm{BIR}$ 의 신용등급 값이 1 이라면, $\mathrm{AR}$ 의 신용등급 값은 이보다는 큰 2 3이라는 의미가 되며, 이는 등급디플레이션에 해당된다. $\mathrm{DIFF}$ 값이 2 이면 $\mathrm{AR}$ 등급과 $\mathrm{BIR}$ 등급이 일치하는 경우가 되고, $\mathrm{DIFF}$ 값이 3 이면 $\mathrm{AR}$ 등급이 $\mathrm{BIR}$ 등급보다 우수한 등급, 즉 등급인플레이션이 된다. $\mathrm{AR}$ 과 $\mathrm{BIR}$ 신용등급을 결정하는 설명변수 $x_{k}$ 로는 아래의 변수들을 사용하였다.

$$
\begin{aligned}
\text { Rating }_{i, t}= & f(\text { 기업규모, 유동비율, 부채비율, 매출비율, } E B I T \text { 비율,순이익비율, } \\
& O C F, \text { 감가상각비율, 변동성 (매출액, 영업이익 }), \text { 거시경제변수) }
\end{aligned}
$$

마지막으로 패널분석에서는 그룹의 이질성을 나타내는 오차항을 고정효과를 볼 것인지 확률효과로 볼 것인지에 따라 결과가 달라지기도 한다. 하우스만 검정결과 고정효과모형이 
한국증권학회지 제49권 6호 (2020)

더 적절한 것으로 판단되어 고정효과 모형을 채택하였다. 앞서 기술한 분석방법에 따른 추정치 산출에는 STATA를 사용하였다.

\section{4. 실증분석}

\section{1 회귀분석}

본 연구는 재무변수 등의 설명변수가 신평사의 사전적 신용등급(AR)과 사후적으로 시장에서 산출되는 채권내재등급(BIR)에 미치는 영향, 나아가 개별 설명변수의 $\mathrm{AR}$ 과 $\mathrm{BIR}$ 등급에 대한 민감도 차이가 양 신용등급간의 차이, 소위 등급인플레이션이나 등급디플레이션에 미치는 영향을 분석한다. 재무변수가 신용등급(AR)에 미치는 영향에 대한 분석은 선행연구가 제법 축적되었으며 채권내재등급(BIR)에 미치는 영향은 Ahn et al.(2016)에서 처음으로 분석되었다. 본 연구는 채권내재등급(BIR)의 결정요인을 주된 분석중 하나로 하고 있다. 하지만 Ahn et al.(2016)과 달리 회귀분석시 재무제표뿐만 아니라 거시지표도 함께 고려하였다. BIR이 경기상황, 시중 유동성이 미치는 금리 스프레드의 영향을 받는 지표란 점과, 경기 악화시에는 기업의 신용등급이 악화되기 십상이고 산업활동과 수출입 동향이 기업의 업황에 영향을 미치기 때문에 거시경제 변수도 사업위험으로 고려하는 것이 필요하기 때문이다. 또한 재무제표 고유 설명력을 파악하기 위해서는 거시경제 지표가 신용등급에 미치는 영향력은 통제(별도 설명변수화)되는 것이 바람직하기 때문이다. 종전의 연구들(2013년까지 시계열자료 활용)보다 시계열자료를 2019년 말까지 확대하였고, 고정효과 패널분석으로 개별기업의 내재된 특성(time-invariant)을 제함으로서, 이에 따른 추정 편의도 제거하였다. 이러한 설정하에서 설명변수들이 $\mathrm{AR}$ 과 $\mathrm{BIR}$ 등급에 미치는 영향, 그리고 양 등급에 대한 민감도 차이로 등급불일치 원인을 파악하고자 하였다. 마지막으로 Ahn et al.(2016)의 연구에 사용된 프로빗이 아닌 로짓 분석을 시도하였다. 양자간에 통계적으로 큰 차이는 없지만, 로짓의 경우 오즈비(odds ratio) 분석이 가능하다는 장점이 있다.

재무변수로는 자산, 유동자산, 부채, 매출, 매출총이익, $\mathrm{EBIT}$, 순이익, $\mathrm{OCF}$, 감가상각비, 매출액표준편차, 영업이익표준편차를 사용하였다. 그리고 거시경제 지표로는 통화지표인 $\mathrm{MMF}$, M2와 기간별 금리(3개월, 1년, 5년), 경제성장률, 순상품교역조건지수를 사용하였다.18) 나아가 국내의 고유특성인 대기업 출자 기업군의 영향력도 함께 고려하였다. 기존연구 중 Kang et al.(2015), Ahn et al.(2016)에서 지적된 대기업집단에 대한 등급인플레션 현상, 등급인플레이션 발생 산업군을 고려해서, 이러한 특징이 패널분석시에도 여전히 유효한지, 또 영향력이 있다면, 이들 집단이 보유한 어떠한 특성에 기인한 것인지를 규명하고자 한다. 이를 위해 대기업더미, 등급인플레이션 업종 더미 등도 설명변수로 설정하였다. 마지막으로 Oh and Chung(2015)의 연구에서 지적한 경기저점(trough)에서는 등급하향이 많아지는 현상을 검증하기 위해 경기 하강기에 대한 더미 변수도 설정하였다.

18) 수출입동향 지표로 수출물량지수, 수출금액지수, 순상품교역조건지수를 사용해 회귀분석한 결과, 가장 설명력이 높은 변수를 사용하였다. 


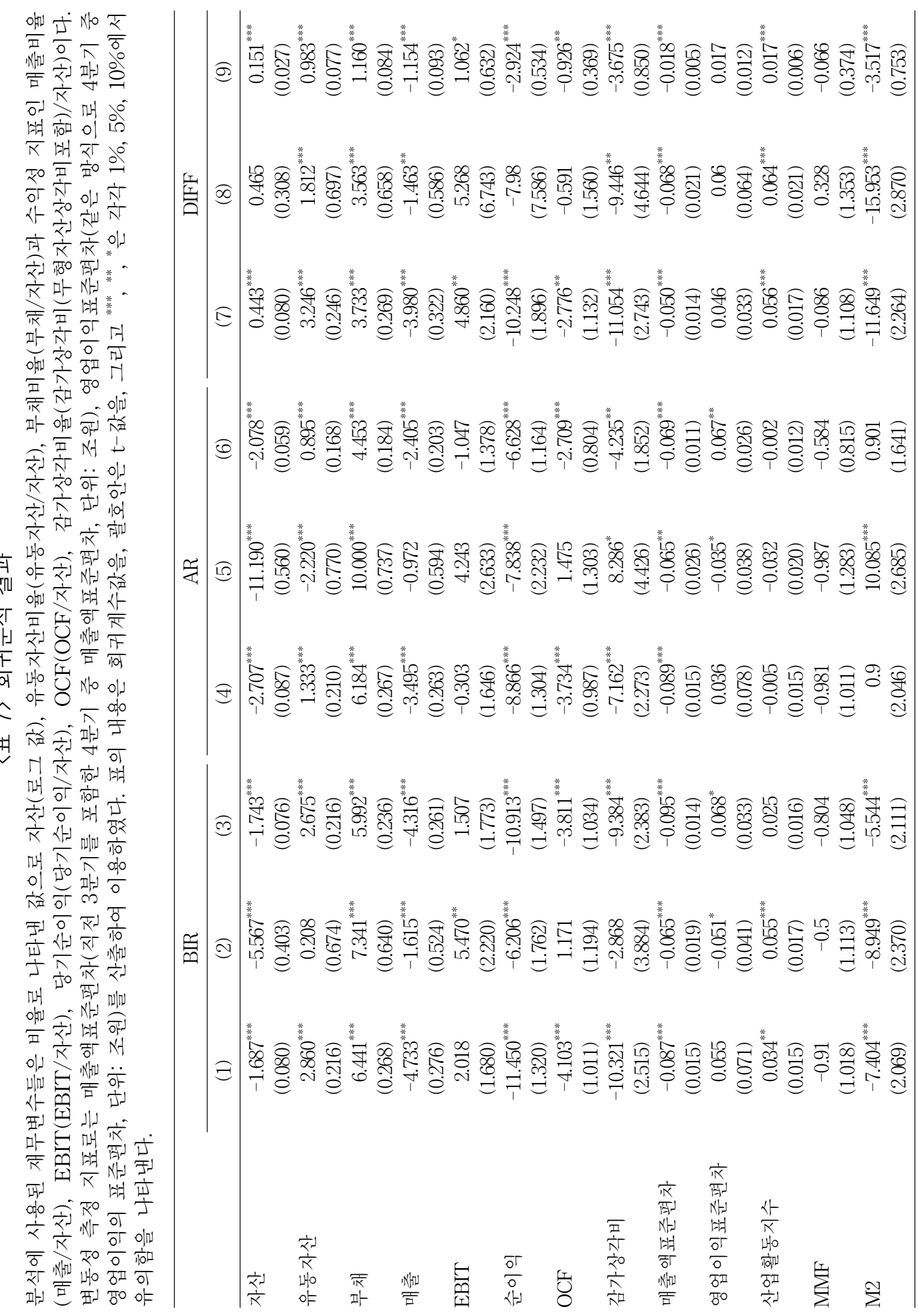


한국증권학회지 제49권 6호 (2020)

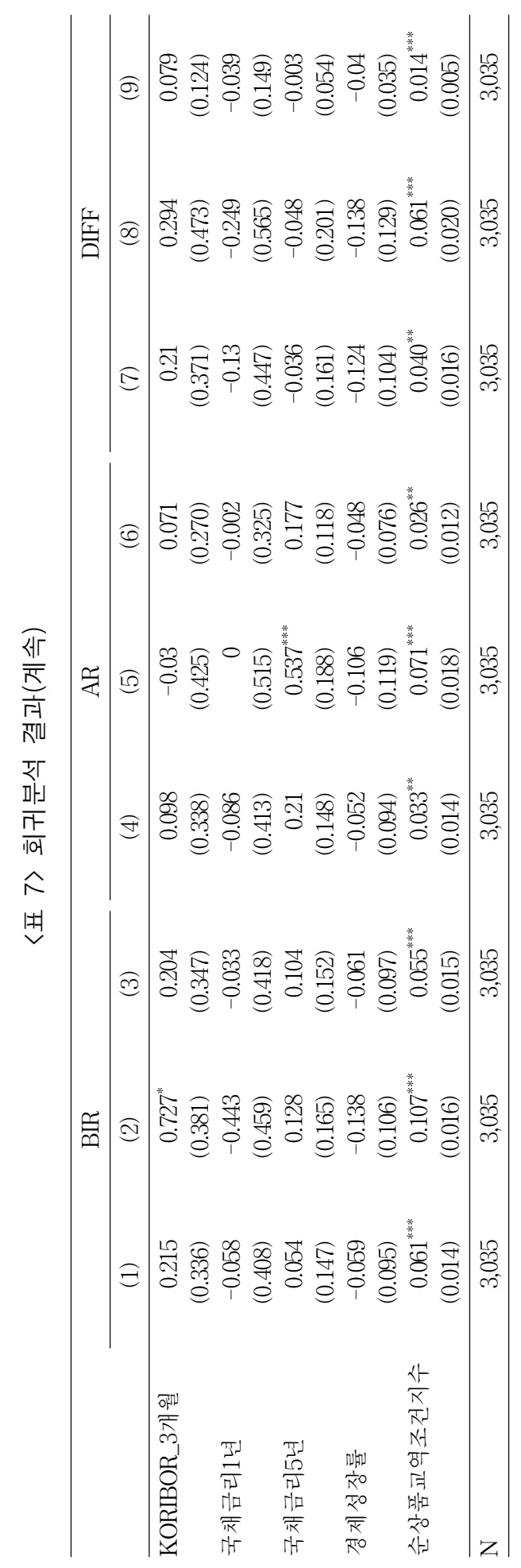


<표 7>은 기업재무변수와 거시경제변수를 설명변수를 사용해 단순 순서형 로짓, 패널형 순서형 로짓, 선형회귀 방법순으로 $\mathrm{BIR}, \mathrm{AR}, \mathrm{DIFF}$ 에 대해 회귀분석한 결과이다. 구체적으로 모형 $1,4,7$ 은 패널분석이 아닌 단순 순서형 로짓 분석, 모형 $2,5,8$ 은 순서형 로짓 모형의 패널 분석이다. 그리고 모형 $3,6,9$ 는 선형회귀분석(OLS)의 결과로 단순 분석과 패널 분석에서 도출된 계수의 방향과 유의성의 참고자료로 제시하였다.

<표 7>의 내용을 요약하면 다음과 같다. 먼저 재무변수에 대한 분석이다. 부채는 $\mathrm{BIR}, \mathrm{AR}$ 로 표시되는 신용등급에 부정적(양(+)의 계수)인 영향이 유의한 것으로 나타났다. 반면에 자산, 순이익, 매출액, 그리고 매출액표준편차와 영업이익표준편차는 유의하게 신용등급을 개선(음(-)의 계수)시키는 것으로 나타났다. 자산, 부채, 수익성과 같은 재무제표의 신용등급에 대한 영향력은 새로운 결과가 아니다. Ahn et al.(2016)에서 부채비율과 영업이익 변동성은 신용등급(AR, $\mathrm{BIR}$ )을 악화시키는 것으로, 자산, 순이익, $\mathrm{OCF}$ (영업현금흐름), $\mathrm{EBITDA}$, 유동자산은 신용등급을 개선시키는 것으로 나타났는데, 본 고의 분석도 동일하다. 물론 소소한 차이는 있다. Ahn et al.(2016)과 부호의 방향과 유의성이 정확히 일치하는 곳은 부채와 자산, 순이익뿐이며, OCF, EBIT, 유동자산의 경우 본고에서는 부호의 방향이나, 유의성 여부가 분석방법에 따라 일치하기도 하고 엇갈리게도 나타났다.19) 이것은 <표 7>에서 확인해 볼 수 있다. 매출액은 $\mathrm{BIR}, \mathrm{AR}$ 등급을 모두 개선시키지만, $\mathrm{AR}$ 에 대한 패널 분석에서는 유의성이 떨어지는 것으로 나타났다.20) 감가상각은 $\mathrm{AR}$ 에 대한 패널분석시 신용등급을 하향시켰지만, $\mathrm{BIR}, \mathrm{AR}$ 에 대한 다른 모형 모두에서는 등급을 개선시키는 것으로 나타났다.

본 연구가 주목하는 결과 중 하나는 표준편차, 즉 변동성의 신용등급 개선효과이다. Ahn et al.(2016)에서 영업이익의 변동성은 신용등급을 악화시키지만, 매출액의 변동성은 신용등급이 개선시켰다는 결과가 있다. 이런 모순된 현상을 놓고, 上記 연구에서는 영업이익 변동성 확대는 기업에게 위험이지만, 매출액 변동성의 확대는 기업의 성장세를 의미하기 때문에 좋은 시그널 이라고 해석하였다. 일반적으로 변동성의 확대는 기업의 미래에 대한 불확실성이 높아진 것이어서 신용평가에 부정적일 수 있다. 반면에 성장세거나 수익성이 개선되는 기업인 경우 영업이익과 매출액의 표준편차는 시차를 두고 오히려 확대될 가능성이 높다. 결국 두 가지 상황이 모두 가능한 상태에서 어느 쪽이 맞는지, 아니면 어느 효과가 더 강한 것인지 대한 질문으로 귀결된다. 본 연구에서는 재무변수와 거시경제변수를 설명변수로 함께 통제한 상태에서 패널기법을 통해 기업의 내재된 고유한 특성마저 통제할 경우, 이들 두 가지 변동성이 AR과 BIR 신용등급에 모두 우호적이라는 것을 새롭게 발견하였다. <표 7>의 (1), (4) 모형은 패널이 아닌, 단순 순서형 로짓 모형으로 Ahn et al.(2016)처럼 영업이익의 변동성 확대가 신용등급 악화를, 매출액 변동성

19) 본고에서는 $\mathrm{EBIT}, \mathrm{OCF}$ 를 동시에 설명변수로 사용한데 따라 Ahn et al.(2016)와 달리 EBIT가 부정적인 영향을 미치는 것으로 일부모형(BIR에 대한 패널형 로짓)에서 나타났으나, $\mathrm{EBIT}, \mathrm{OCF}$ 를 각각 영업현금흐름에 대한 별도의 설명변수로 사용할 경우 양 변수 모두 신용등급에 긍정적인 것으로 나타났다.

20) $\mathrm{AR}$ 에 대한 패널분석의 경우 순이익, $\mathrm{EBIT}$, 매출총이익을 추가로 control할 경우에는 매출액의 유의성이 살아났다. 
한국증권학회지 제49권 6호 (2020)

확대가 신용등급을 개선시키는 것으로 나타났다. 하지만 이를 패널분석으로 확장하자, (2), (5) 모형에서 부호의 계수가 변경되고 있다. 이런 점에서 단순한 순서형 프로빗(로짓)보다는 패널 분석이 계수의 편의 가능성을 축소시키고 있는 것으로 보인다.21)

다음은 재무변수 등 설명변수들이 AR과 BIR등급결정에 미치는 민감도 차이(gap)에 대한 분석이다. <표 7>에서는 이러한 차이를 등급불일치정도 $(\mathrm{DIFF})$ 로 정의하고 종속변수로 설정 하였다. $\mathrm{DIFF}$ 변수가 1 인 것은 $\mathrm{BIR}$ 의 신용등급이 $\mathrm{AR}$ 보다 좋은 경우로 등급디플레이션을, 이

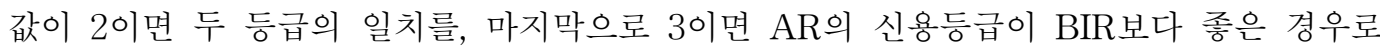
등급인플레이션을 의미한다.

우선 재무변수에 대한 결과이다. 자산(및 유동자산), 부채는 유의하게 등급인플레이션을 초래하는 것으로 나타났다. 그리고 매출액, 감가상각, 매출액표준편차는 등급디플레이션을 유의하게 초래하는 것으로 나타났다. 다음은 거시경제변수가 미치는 영향인데 순상품교역조건 지수와 산업활동동향지수는 등급인플레이션을, 반대로 유동성 지표 중 $\mathrm{M} 2$ 는 등급디플레이션을 초래하는 것으로 나타났다.

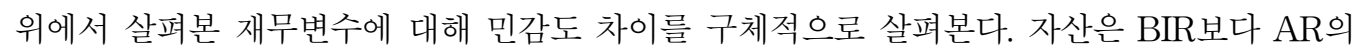
신용등급 개선에 더 큰 영향력을 미침에 따라 자산 증가는 등급인플레이션을 초래하는 것으로 나타났다.22) 반면 부채의 경우에는 이러한 해석이 적용되기가 어려운 상태이다. 단순 순서형 로짓에서는 부채가 등급을 악화시키는 변수로써 부채 증가시 BIR등급이 AR보다 더 빠르게 하향조정시킴에 따라 등급인플레이션이 발생하였지만, 패널 순서형 로짓에서는 $\mathrm{AR}$ 등급이 $\mathrm{BIR}$ 보다 계수 값이 더 크게 나타나고 있기 때문이다.

$\mathrm{DIFF}$ 변수에 대한 분석표에서 자산과 부채는 등급인플레이션을 초래하는 변수이지만, 자산의 경우 $\mathrm{BIR}$ 과 $\mathrm{AR}$ 간 민감도 차이에 따라 등급인플레이션이 발생하는 맥락을 설명할 수 있지만, 부채는 모형(패널형과 단순 순서형 로짓)에서 민감도가 엇갈리게 나와 등급인플레이션의 발생 원인을 자산과 같은 방식으로 설명하기는 곤란하다. 반면에 매출액, 매출액표준편차, 순이익, 그리고 감가상각은 전반적으로 시장(BIR)이 신평사(AR)보다 빠르게 등급을 개선시킴에 따라 등급디플레이션이 발생하는 것으로 보인다. 이들 변수들은 수익성과 관련성이 높은 설명변수란 점에서, 수익성지표들에 대해서는 시장(BIR)의 평가가 신평사(AR)보다 민감하게 반응한다고 볼 수 있을 것 같다.

거시경제변수의 민감도 분석 결과이다. 순상품교역조건지수는 $\mathrm{AR}$ 과 $\mathrm{BIR}$ 등급을 모두 악화시키는 변수인데, 특히 BIR을 더 빠르게 악화시켜 DIFF변수에 대해서는 등급인플레이션을 초래하는 것으로 나타났다. 순상품교역조건지수란 수출상품과 수입상품의 가격비율을 통하여 산출되며 이 지표의 악화는 경제성장에 부정적인 영향을 미친다. 따라서 반대로 이 지수의 상승으로 경제 성장에 기여한다면, 주식시장이 반등하며 상승하는 경향을 보이므로 상대적으로

21) 다만, 자산액 대비 비율로 변동성 값을 산출할 경우 매출액 표준편차의 부호는 변동이 없으나 영업이익률 표준편차의 경우 단순형로짓에서는 계수가 유의하게 플러스로 변하는 한계가 나타났다.

22) 반면에 유동자산의 경우 자산 감소로 인한 등급 하락 효과가 BIR에서 더 강하게 나타났기 때문에 등급인플레이션이 발생하고 있다. 
이러한 경기확장국면에는 채권시장이 축소됨에 따라 $\mathrm{AR}, \mathrm{BIR}$ 의 등급 악화를 일으킨다고 할 수 있다.23) 산업활동지수는 BIR등급 악화에 유의하게 영향을 미치며 AR에선 유의하진 않지만 등급 개선에 기여하는 것으로 확인된다. 따라서 $\mathrm{DIFF}$ 에서는 등급인플레이션이 발생하는 변수로 확인된다. $\mathrm{M} 2$ 는 $\mathrm{BIR}$ 에서는 등급 상향, $\mathrm{AR}$ 에서는 등급을 하향시켜 $\mathrm{DIFF}$ 에서는 등급디플 레이션을 초래하는데, 이는 $\mathrm{M} 2$ 통화량이 늘어나게 되면 시중금리가 하락하여, $\mathrm{BR}$ 의 기초자료인 금리가 하향되면서 신용등급이 전반적으로 개선되는 반면 신평사는 M2가 확대될 때 신용평가 등급을 엄격히 하는 경향 때문이라고 해석할 수 있다. 한편 설명을 하지 못한 다른 변수들24)의 경우, 부호의 불일치 또는 유의성이 떨어지게 나타났는데 이것은 아래의 표를 참조하기 바란다.

다음으로는 앞서 살펴본 유의한 변수들에 대해 오즈비 $(\exp (\beta))$ 를 구하여25) 분석한 결과이다. 이를 통해 설명변수의 값의 변화에 따라 신용등급에 미치는 영향을 살펴봄으로써 더욱 정확하게 분석할 수 있게 될 것이다. 설명변수에 대한 회귀계수 $(\beta)$ 를 $\exp (\beta)$ 로 변환시킨 값은 동 변수를 한 단위 증가시킬 때 얻는 종속변수의 오즈비의 배수(변화26))를 알 수 있다. 본 연구에서는 양의 회귀계수 방향은 등급의 악화를 의미하며 이에 따라 오즈비가 1 보다 큰 경우는 등급하락의 가능성 증가로 해석한다. 민감도 분석을 위한 등급차이변수(DIFF)에서는 오즈비가 1보다 큰 경우를 등급인플레이션 발생 가능성으로 해석할 것이다.

먼저 설명변수인 재무변수 중 자산(및 유동자산)에 대해 살펴본다. 자산 1단위(1조 원) 증가가 등급인플레이션에 대한 오즈비 $\left(O R_{D I F F}\right)$ 가 1.04 배(유동자산은 1.015배)로 나타났다.27) 동일한 자산 1 단위 증가가 $\mathrm{BIR}$ 에 대한 오즈비 $\left(O R_{B I R}\right)$ 는 $0.99, \mathrm{AR}$ 에 대한 오즈비 $\left(O R_{A R}\right)$ 는 0.96 로 $\mathrm{AR}$ 에 대한 오즈비가 더 작게 나타나 그 결과 $\mathrm{AR}$ 의 신용등급 개선 가능성이 $\mathrm{BIR}$ 에 비해 크다. 이 때문에 양 등급간 비교로 나타나는 등급인플레이션 가능성에 대한 오즈비가 1 배보다 크게 되는 것이다. 매출변수의 등급인플레이션에 대한 오즈비 $\left(O R_{D I F F}\right)$ 는 0.955 배이어서, 이 경우에는 등급디플레이션 가능성이 높다. 부채의 등급인플레이션에 대한 오즈비 $\left(O R_{D I F F}\right)$ 는 1.02 배로 등급인플레이션 가능성이 등급디플레이션보다 상대적으로 높다.28) 다음으로 거시경제 변수 중 산업활동지수의 $\mathrm{BIR}$ 에 대한 오즈비는 $O R_{B I R}=1.049, \mathrm{AR}$ 에 대해서는 $O R_{A R}=0.97$ 로 $\mathrm{BIR}$ 의 등급 하락 가능성이 더 높다. 이 결과 등급인플레이션 가능성에 대한 오즈비, $O R_{D I F F}$ 는

23) 금융위기 이후, 신용확대(credit expansion)와 주택시장이 거시경제 순환에 지대한 영향을 미치고 있다고 알려져있다. 특히 익명의 심사자가 제안한 주택지수(구체적으로는 수도권아파트지수)를 거시경제 설명변수로 추가하여 보았는데, 다른 설명변수의 크기나 유의성에는 별다른 변동이 없었지만, 주택지수가 유의해지면서 순상품교역지수의 유의성은 떨어지는 것으로 나타나기도 하였다.

24) 유동자산과 이익률(EBIT, 매출총이익), OCF, 금리 변수(3개월, 1 년, 3 년, 5 년 금리).

25) 부록<표 13>.

26) $\Delta \%=100(\exp (\beta)-1)$.

27) <표 7> <표 10>까지 이루어진 실증분석의 설명변수는 자산은 로그 값, 여타 재무변수는 자산으로 나눈 비율을 사용하였다. 하지만 여기서 오즈비를 통해 설명변수 한 단위 변화를 보다 쉽게 파악하기 위하여 비율변수가 아닌 재무변수의 원래 수준(각 변수를 십조 단위에서 절사한 값)을 사용하였다.

$28)$ 등급인플레이션에 대한 오즈비 $\left(O R_{D I F F}=1.02\right.$ 배 $)$ 는 $2 \%$ 증가하는 것으로 확인된다. 
한국증권학회지 제49권 6호 (2020)

1.07 로 나타났다. 순상품교역조건지수는 $\mathrm{BIR}, \mathrm{AR}$ 모두 등급 악화에 영향을 주는 변수인데 오즈비 $\left(O R_{B I R}=1.1, O R_{A R}=1.06\right)$ 에서 $\mathrm{BIR}$ 에 대한 등급악화 가능성이 더 큰 것으로 나타났으며, 이 결과 순상품교역조건지수 상승시 등급인플레이션에 대한 오즈비 $\left(O R_{D I F F}=1.06\right)$ 가 증가하는 것으로 확인된다. 한편, $\mathrm{M} 2$ 설명변수의 BIR에 대한 오즈비는 0.00229)로 매우 낮아서, $\mathrm{M} 2$ 한단위 $\left(1 \% \mathrm{pt}\right.$, 설명변수가 $\left.\log \left(M_{2}\right)\right)$ 증가가 BIR등급에 대한 오즈비를 0.002 수준으로 급격히 축소시킨다. 반면에 $\mathrm{AR}$ 에 대한 오즈비는 1 배보다 커서 $\mathrm{AR}$ 등급에 대한 오즈비는 크게 상승되기 때문에, 양 등급간의 비교인 등급인플레이션에 대한 오즈비는 1 배보다 커서 등급디플레이션 가능성이 커진다. 이상의 기술에 사용된 오즈비 값들은 부록의 <표 $13>$ 에서 확인할 수 있다.

\section{2 더미변수 추가 분석}

다음으로는 대기업여부, 경기 후퇴기 그리고 등급인플레이션 업종이 신용등급(AR, BIR)과 민감도 차이로 인한 등급불일치(등급인플레이션 또는 등급디플레이션)에 미치는 영향을 분석한다. 이를 위해 3종류의 더미변수를 도입한다.

먼저 대기업이 등급 인플레이션을 초래하는지 여부이다. Kang et al.(2015)은 자산규모 50위 이상 기업집단인 경우 등급 인플레이션 가능성이 높다는 것을 보였다. 또한 Ahn et al.(2016)은 대기업과 달리 중소기업에서는 $\mathrm{AR}$ 과 $\mathrm{BIR}$ 모두 하향 편의되고 있다고 밝혔다. 이들 연구는 2013년까지 자료를 이용한 분석인 반면에 본 연구는 시계열을 2019년까지 연장하여 대기업집단에 대한 등급편의 현상을 분석하였다. 분석결과 대기업에 대해서는 신용등급 상향 편의가 존재하지만, 기존 연구와 달리 그 유의성이 떨어지며, 대기업이란 사실보다는 부채비율이 축소되거나 매출액이 증가한데 따라 등급인플레이션 발생 가능성이 높아지는 것으로 나타났다.

다음은 경기순환주기가 $\mathrm{AR}$ 과 $\mathrm{BIR}$ 등급 결정과 양 등급에 미치는 민감도 차이에 대한 분석이다. 2015년 전후 국내경기 하강과 겹친 해외수주 둔화에 따른 조선·해운업의 구조조정, 대우조선해양 분식회계 사태로 회사채에 대한 평가등급의 늦장 조정, 이로 인한 등급인플레이션이 화두가 되면서 신용평가제도 개편 요구가 대두된 바 있다. Oh and Chung(2015)는 국내 3개 신평사의 과점과 더불어 신평사 등급의 상대적 안정성으로 인한 늦장 조정을 등급인플레이션의 한 요인으로 지적하였다. 이에 본고는 경기하강기 더미변수와 재무변수의 교차항을 고려해 분석하였다. 분석 결과 경기하강기 더미변수의 신용등급 악화 현상은 $\mathrm{AR}$ 과 $\mathrm{BIR}$ 등급 모두에 유의한 것으로 나타났다. 즉 경기하강기로 인해 산업위험이 상승할 경우 이것은 즉각 신용등급에 반영되고 있었다. 또한 민감도 차이에 따른 등급인플레이션 현상도 목격되었다. 특히 경기하강기에 수주산업에서 발생하는 자산 축소와 $\mathrm{EBIT}$ 감소, 감가상각의 증가가 $\mathrm{BIR}$ 등급의 빠른 하락을 초래하고, 이 때문에 등급인플레이션이 발생하는 것으로 나타났다.

마지막으로 등급인플레이션이 현저한 업종에 대한 분석이다. 건설업과 같은 업종에서는 AR과 $\mathrm{BIR}$ 평가등급 악화라는 낙인효과가 존재하였다. 또한 신평사(AR)가 시장(BIR)보다 등급을 더 보수적으로 평가하는 속성이 입증되었다. 신평사등급(AR), 시장평가등급(BIR), 민감도

29) $p /(1-p)=0.002$ 일 때, 등급악화 확률 $\mathrm{p}$ 는 0.001996 이어서, 등급상승확률 $\mathrm{p}$ 는 약 $99.8 \%$ 이다. 
차이에 따른 등급불일치(DIFF)에 미치는 상기 3종류 더미변수, 그리고 더미변수와 재무변수 교차항간에 분석 결과는 아래 표에 정리되어 있다.

구체적으로 아래 3 개의 표를 개관하면 다음과 같다. 먼저 <표 8>은 대기업 더미변수(BIG)를 도입한 결과이다. 순서형 로짓에서 동 더미변수(BIG)는 신평사와 시장평가(AR, $\mathrm{BIR}$ ) 모두에서 음의 계수 값(-)으로 신용등급을 유의하게 개선시켰다. 즉, 대기업에 대한 등급 상향편의를 의심해 볼 수 있다. 하지만, 기업의 측정되지 않는 고유 변수를 통제한 패널(순서형 로짓)분석 에서는 대기업 더미의 계수 값이 여전히 (-)였지만, 유의하지는 않았다. 즉 등급 상향이 유의하다고 볼 수 없었다.

나아가 등급 상향 편의를 발생시키는 원인을 규명하기 위해 대기업 더미와 재무변수간의 교차항을 도입하여 분석하였다. 교차항 도입시 대기업 더미(BIG)는 시장평가(BIR)에서는 유의하게 등급을 상향시키지만 신평사 등급(AR)은 오히려 하향30)되는 것이 확인되었다. 즉 신평사는 대기업에 대해 오히려 보수적으로 등급을 하향시키는 경향이 나타났다. 그렇다면, 등급디플레이션 가능성을 우려해 볼 수 있다. 이를 확인하고자 등급불일치(DIFF)변수를 종속 변수로 하고 재무변수와의 교차항을 넣어 분석했더니 순서형 로짓 분석에서 예상과 달리 대기업 더미(BIG) 변수는 등급 인플레이션이 유의하게 나타났다. 하지만, 패널 분석(순서형 로짓)에서는 예상했던 등급디플레이션이 나타났는데 유의하지는 않았다. 따라서 대기업이라고 해서 등급 인플레이션이나 등급디플레이션이 발생한다고 결론지을 수는 없었다. 이 점은 기존의 연구들과 다른 발견이다. 다만, 재무변수와 교차항 중 (단순 및 패널 순서형 분석에서) 부채비율, 매출액은 시장평가(BIR) 등급을 유의하게 상향시키는 것으로, 자산(유의하진 않음)과 매출액(유의함)은 신평사(AR) 등급을 상향시키는 것으로 나타났다. 정리하면, 대기업이란 사실만으로 등급인플 레이션이 초래된다고 할 수는 없지만, 대기업인 경우 부채비율(의 감소)이나 매출액(의 상승)에 따라 $\mathrm{AR}$ 과 $\mathrm{BIR}$ 의 민감도 차이가 발생하면서 등급인플레이션이 목격되는 것으로 보인다.

다음으로는 경기순환 주기 31$)$ 가 신용등급에 미치는 영향을 분석하기 위해 경기하강기(DOWN) 더미를 추가하였다. 통계청의 경기순환주기를 참고하여 2011.3 2013.1분기와 2019.1 3분기32)를 경기하강기로 정의하였다. 재무변수에 대한 교차항을 도입하기 이전에 경기하강기 $(\mathrm{DOWN})$ 의 계수 값은 $(+)$ 로 신평사 $(\mathrm{AR})$ 와 시장평가 $(\mathrm{BIR})$ 등급을 모두 악화시키지만 유의하지는 않다. 반면에 재무변수 교차항을 앞에서 같은 방식으로 도입하면 $\mathrm{AR}$ 과 $\mathrm{BIR}$ 모두에 대해 경기하강기 (DOWN) 더미의 유의성이 살아났다.33) 더 나아가 등급불일치(DIFF)변수에 대한 영향 분석 에서는 신평사(AR)에 비해 시장평가등급(BIR)의 신속한 반응으로, 등급인플레이션이 초래되었다.

30) 이 경우 유의하지 않다.

31) 경기순환이란 총체적 경제활동이 경제의 장기 성장추세를 중심으로 상승과 하강을 반복하여 성장하는 현상을 의미하며 경기저점에서 정점까지를 경제활동이 활발한 확장국면, 경기정점에서 저점까지를 경제활동이 위축된 수축국면으로 나누는 이분법이 주로 이용된다.

32) 경제성장률 연 $2 \%$ 이하이다.

$33)$ 다만, 다른 설명변수와 교차되지 않은 경기하강기(DOWN) 변수 계수에 대한 강건성은 추가적인 검증이 필요해 보인다. 


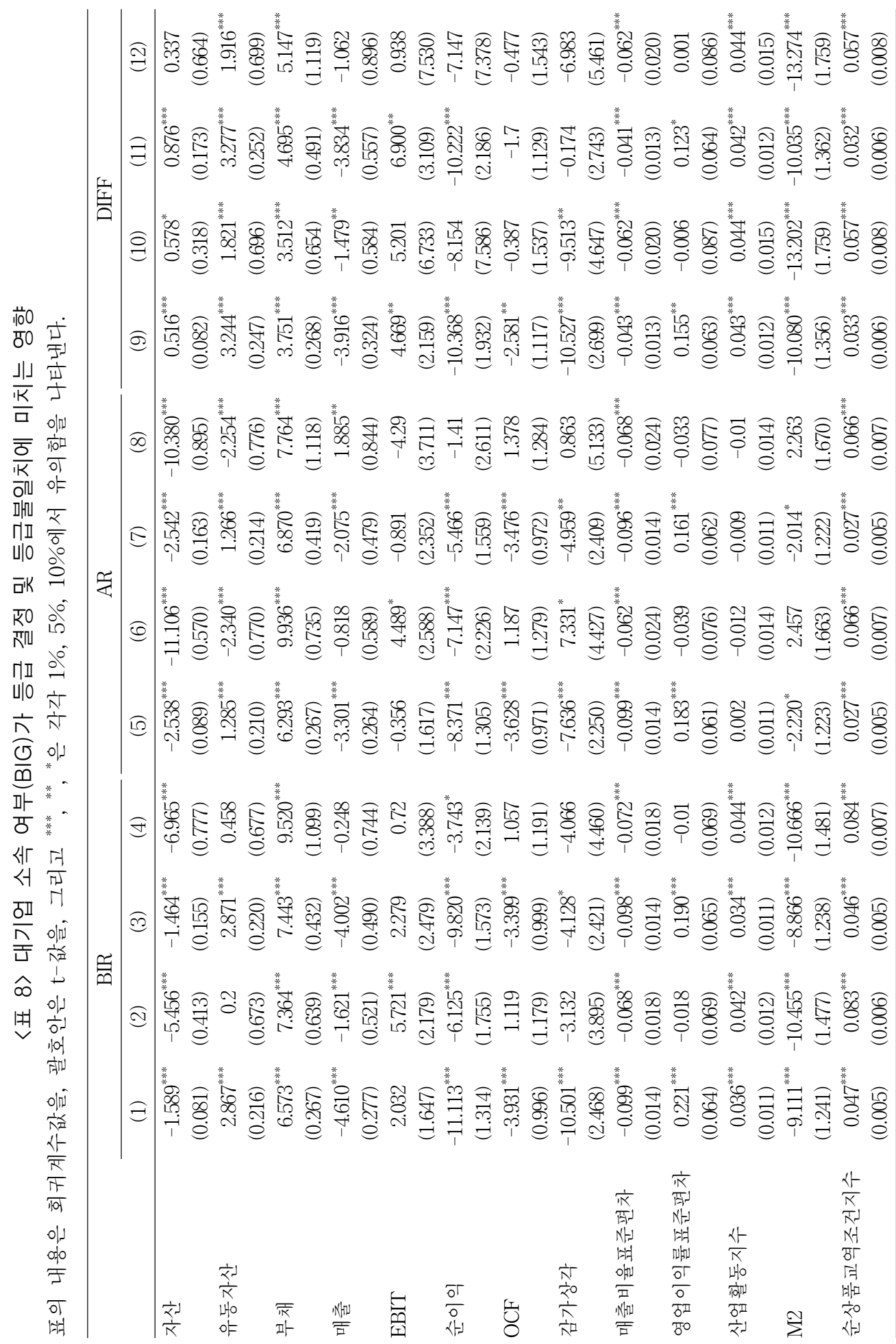




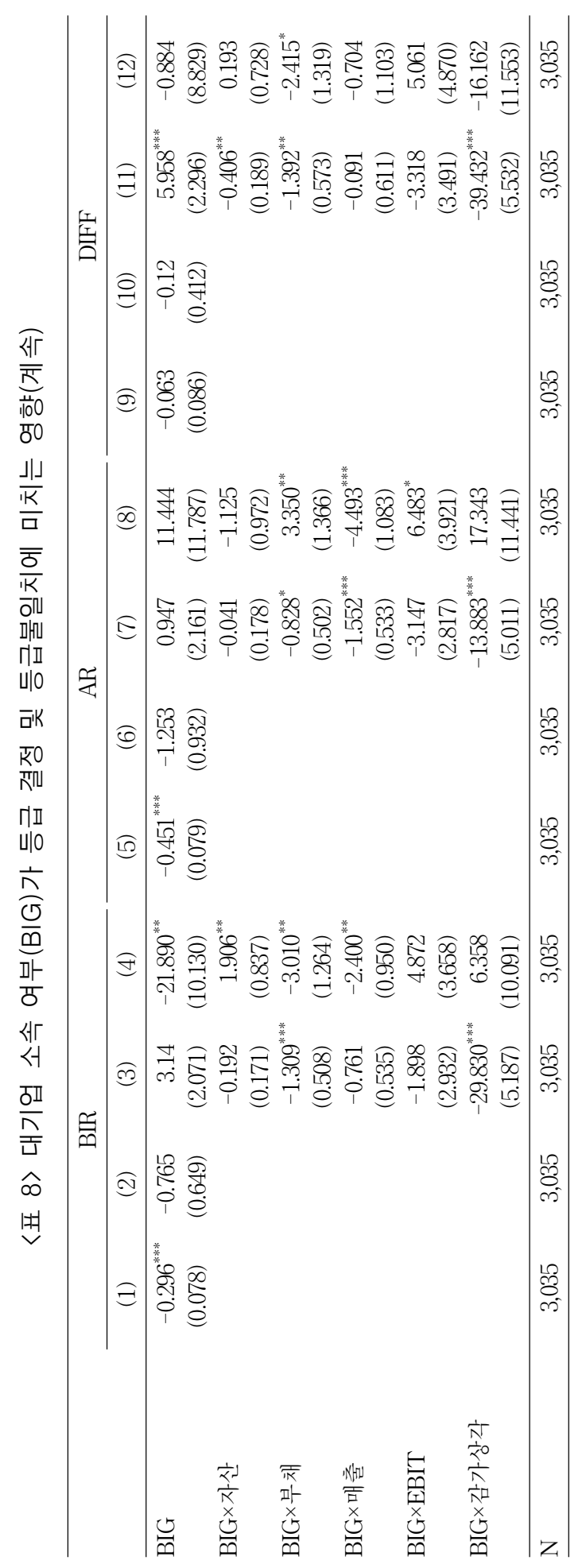




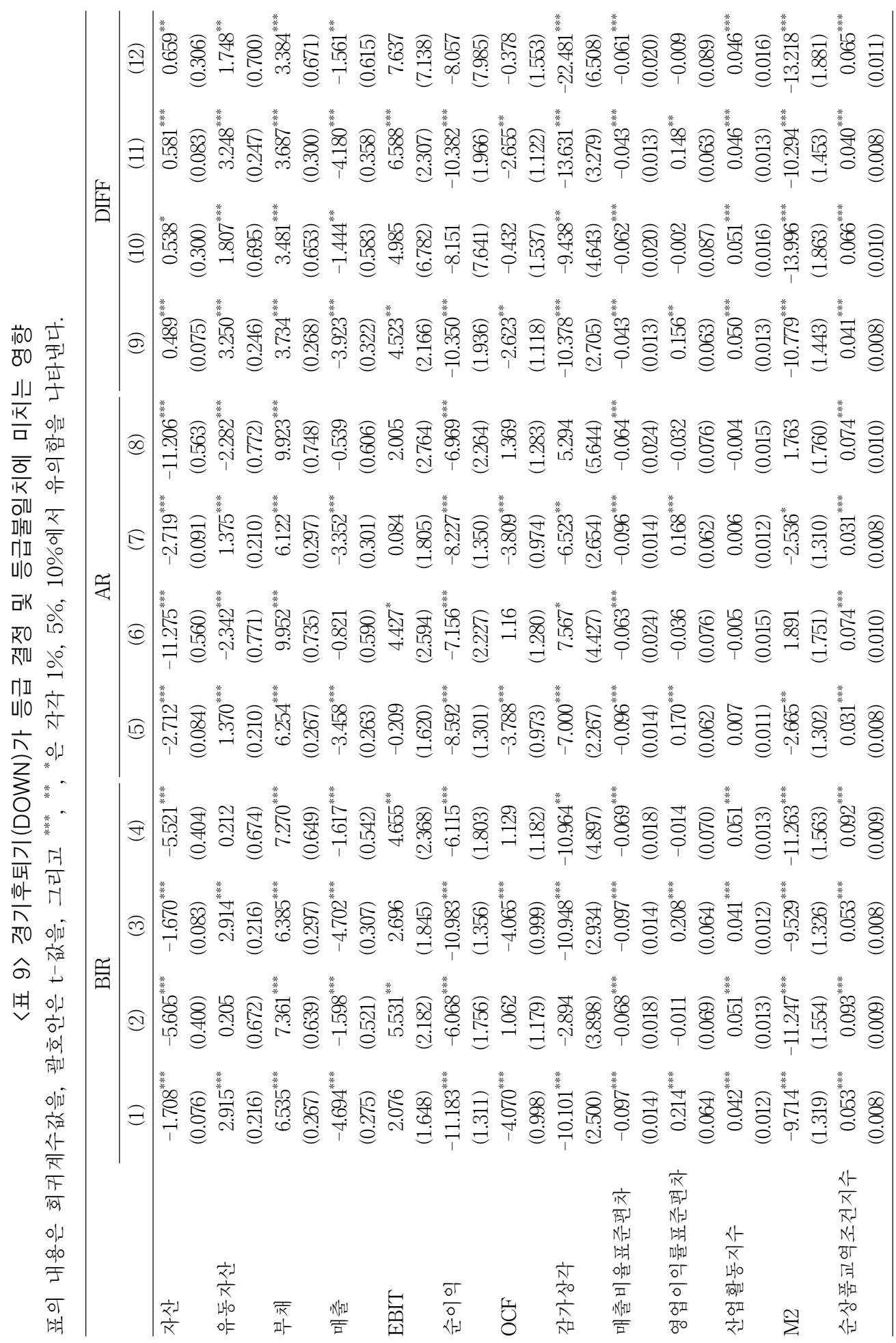




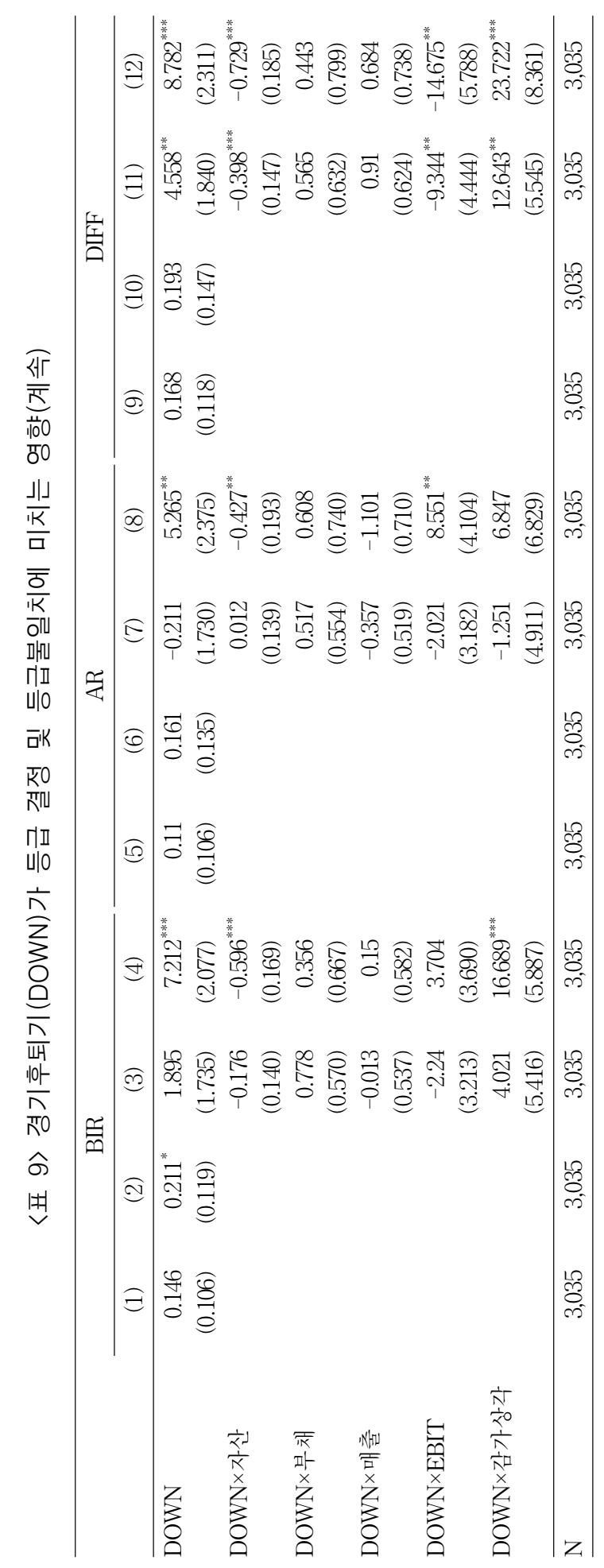




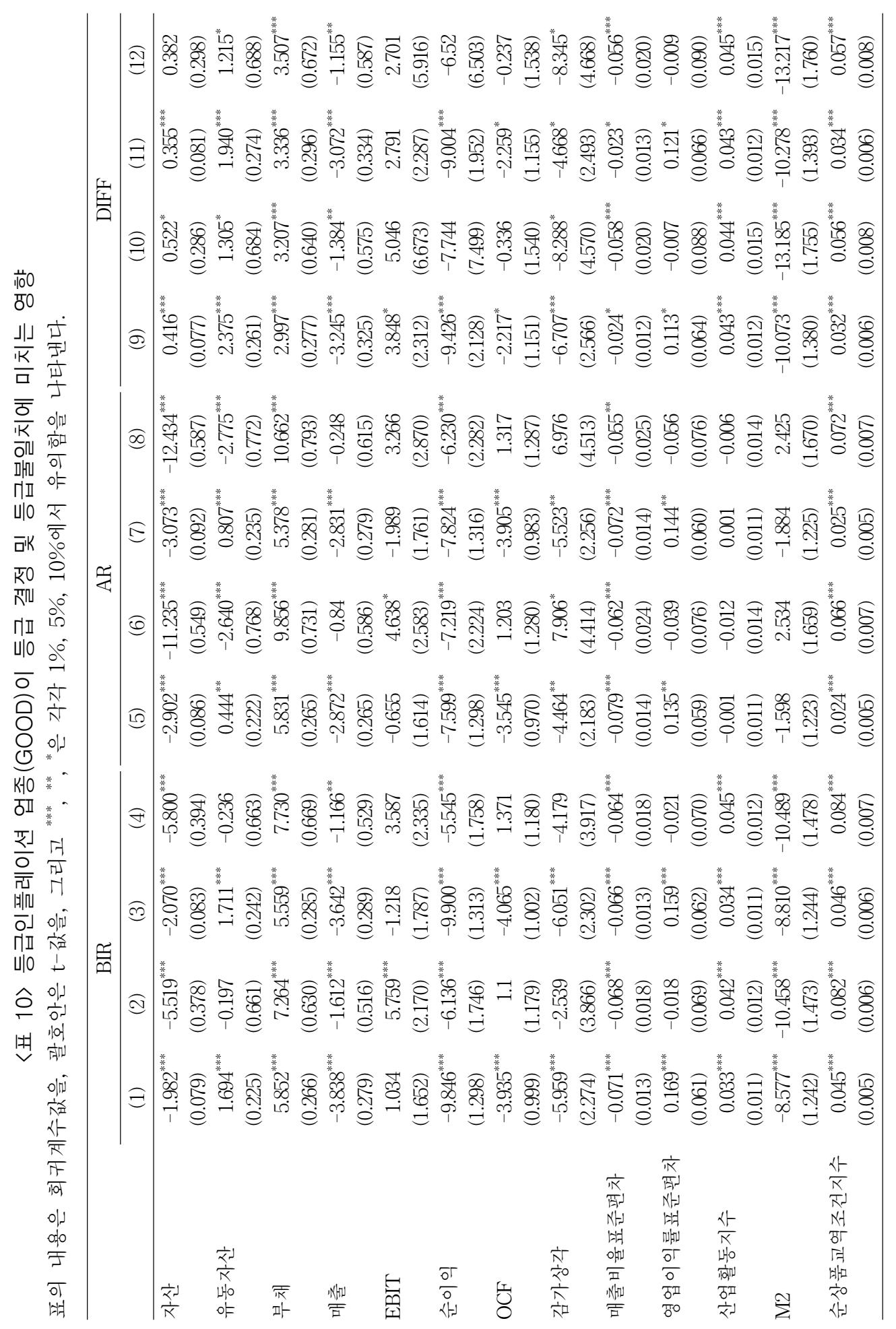


Determinants and Sensitivity of Credit Ratings

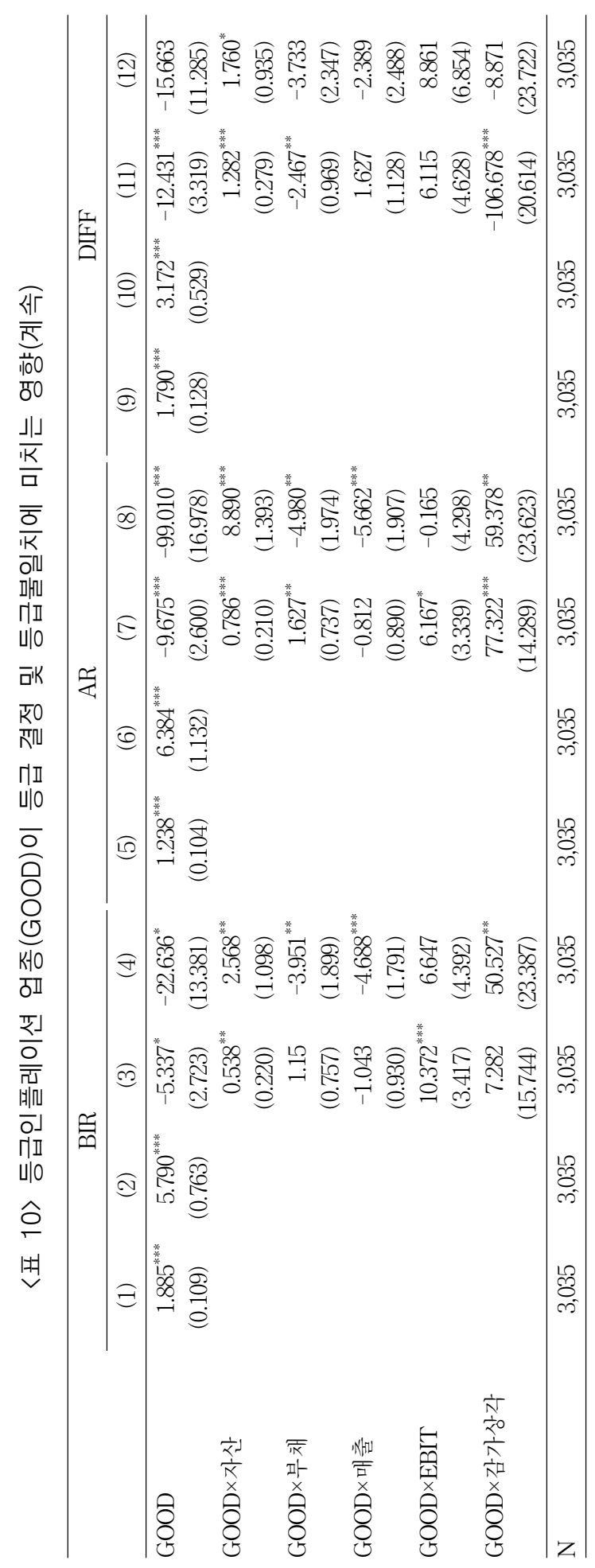


한국증권학회지 제49권 6호 (2020)

이는 경기 악화시 회사채 자금조달에 대한 금리스프레드가 확대되면서, 금리수준에 연동된 시장평가(BIR) 등급의 하락폭이 상대적으로 더 확대된데 따른 결과로 해석된다. 즉 $\mathrm{Oh}$ and Chung(2015)의 전이행렬에서 나타난 AR의 상대적인 안정성이 이와 같은 민감도 차이로 분석되었다고 볼 수 있다. 재무변수와 교차항에 대한 값들은 자산과의 교차항은 등급을 상향시키는 것으로, 그 반대로 EBIT은 신평사(AR) 등급을 유의하게 악화시키는 것으로 나타났다.34) 이는 수주산업처럼 경기하강기에 자산 축소와 이에 수반된 EBIT의 개선이 발생하는 경우 등급악화의 시그널로 작용하는 것으로 해석된다. 한편 등급불일치 $(\mathrm{DIFF})$ 에 대해서는 EBIT와의 교차항의 계수 값은 (-)로 등급디플레이션을 초래하였다. 반면에 시장평가 등급(BIR)에 대해서는 EBIT항은 그 자체로는 $\mathrm{AR}$ 처럼 유의하게 등급을 악화시켰지만, 경기하강기 $(\mathrm{DOWN})$ 와의 교차항이 유의하지는 않았다. 한편 감가상각 변수의 교차항은 전반적인 등급악화(특히 BIR에는 큰 폭으로), 그리고 시장평가 등급 $(\mathrm{BIR})$ 의 높은 민감도로 등급불일치 $(\mathrm{DIFF})$ 변수에 대해서는 등급인플레이션이 목격되었다.

마지막으로는 등급인플레이션이 높은 업종에 대한 분석이다.35) <표 5>에서처럼 $\mathrm{AR}<\mathrm{BIR}$ 의 비중이 높아 등급인플레이션이 현저한 업종인 건설, 운수, 전문과학 산업을 등급인플레이션 업종 $(\mathrm{GOOD})$ 더미로 선정하였다. 이들 업종은 등급불일치 변수( $\mathrm{DIFF})$ 가 종속변수인 경우 업종 $(\mathrm{GOOD})$ 더미의 계수 값이 $(+)$ 로 나타나야 할 것이다. 실제 단순 순서형 로짓 분석, 그리고 패널 분석 모두에서 $(+)$ 로 등급인플레이션이 확인되었다. 그리고 신평사(AR)와 채권내재(BIR) 등급을 종속변수로 할 경우에도 동 업종 $(\mathrm{GOOD})$ 더미 계수 값은 $(+)$ 로 나타나, 해당 업종이라는 사실만으로도 평가등급이 악화되는 소위 낙인효과가 목격되었다. 즉 이들 3 개 업종은 낙인효과와 더불어, 신평사(AR)가 시장(BIR)보다 등급을 더 보수적으로 책정하는 행태가 입증되었다.

한편 동 업종 $(\mathrm{GOOD})$ 더미에 재무변수 교차항을 추가할 경우 업종 더미 자체는 계수의 부호가 $(-)$ 로 변경되어, 등급디플레이션이 관측되었다. 반면에 자산, EBIT, 감가상각과의 교차항의 계수는 유의하게 (+) 값으로 나타났다. 즉, 건설, 운수, 전문과학 업종이란 이유만으로 낙인효과가 나타나기보다는 자산, EBIT, 감가상각의 규모 확대시 등급이 악화됨을 알 수 있다. 또한 등급불일치 변수(DIFF)에 대한 분석에서는 등급인플레이션의 주원인 역시 자산이나 EBIT 규모의 확대로 나타났다.

\section{5. 결론}

본 연구는 국내 회사채 시장에서 신용평가사의 신용등급 $(\mathrm{AR})$ 과 시장의 평가로 결정되는 채권내재등급(BIR)을 사용하여 등급 결정요인과 민감도 차이에 대해 패널분석을 시도하였다. 구체적으로는 회사채 발행 기업의 재무변수와 시장위험을 측정하는 거시경제변수를 사용하여

34) 한편 경기하강기(DOWN) 더미변수와 교차되지 않은 EBIT 자체 항은 유의하진 않았다.

35) 산업분류가 2017년에 10차로 개정되어 과거 연구와 차이가 발생하였다, Kang et al.(2015)에서는 어업, 건설업, 금융보험, 부동산임대업에서 등급인플레이션이 발생한 것으로 나타났으나 산업의 재분류와 시계열 추가로 건설업, 운수, 전문과학서비스에서 등급인플레이션이 나타났다. 
분석하였다. 분석결과 매출과 영업이익의 변동성이 $\mathrm{AR}, \mathrm{BIR}$ 두 신용등급 모두 개선시키는 유의한 변수임을 새롭게 발견하였다. 그리고 기존 연구들에서 재무변수가 AR에 미치는 영향에 대한 연구결과가 BIR등급 결정에도 대부분 유의함을 밝혔다.

한편 이들 재무변수의 $\mathrm{BIR}$ 과 $\mathrm{AR}$ 에 대한 민감도 분석 결과, 자산 및 유동자산은 양 등급을 모두 개선시키지만 자산 증가로 인한 등급 개선효과는 $\mathrm{AR}$ 이 더 크게 반응하고, 반대로 자산 감소로 인한 등급 하락 효과는 BIR에서 더 강하게 나타나 등급인플레이션이 초래되는 것으로 나타났다. 반면에 매출액, 매출액표준편차, 순이익, 그리고 감가상각은 전반적으로 시장(BIR)이 신평사(AR)보다 빠르게 등급을 개선시킴에 따라 등급디플레이션이 발생하였다. 거시경제변수 중 산업활동지수와 순상품교역조건지수는 $\mathrm{BIR}$ 의 등급 악화에 미치는 영향력이 더 커서 등급인플레이션이 발생하였다. 따라서 같은 방향성을 보이는 변수이더라도 민감도 차이로 등급인플레이션이 발생한다는 것을 확인하였다.

마지막으로 더미 변수를 도입하여 등급인플레이션 간의 관계를 분석한 결과를 요약하면 첫째, 대기업이란 이유로 등급인플레이션이 발생하기보다는 이들의 재무적 특성에 기인한 것으로 나타났다. 둘째, 경기후퇴기에는 등급이 전반적으로 하향하며 BIR의 악화 정도가 크게 나타나 등급인플레이션이 나타났다. 셋째, 등급인플레이션이 현저한 업종의 더미 변수는 유의한 양 $(+)$ 의 계수 값을 보였으며 이는 동업종에서 등급을 하향시키는 것으로 나타났다.

본 연구의 한계로 다음의 세 가지를 지적할 수 있다. 첫째, 금리변수에 대한 분석의 한계이다. 금리변수를 설명변수로 채택했지만 만기별로 부호가 상이하고, 분석모형별(단순 선형 회귀분석, 단순 순서형 로짓, 그리고 패널분석)로도 부호의 방향이 상이하게 나와서 의미있는 해석을 도출하지 못하였다. 둘째, 대기업에 대한 등급인플레이션이 상당한 이슈였는데, 본고의 분석에서는 대기업에 등급인플레이션이 있다고 결론 내리기는 어려웠다. 그렇다면 2020년대 들어 신용등급 산정시 대기업에 대한 등급인플레이션이 사라진 것인지, 그리고 그 원인은 무엇인지에 대한 추가 분석이 필요해 보인다. 셋째, 등급결정의 중요한 변수인 시장위험내지 사업위험 변수로 통계청이나 한국은행에서 자료입수가 가능한 거시경제지표를 사용하였다. 하지만 사업위험의 측정에는 시장지위, 경쟁력, 경영관리능력 등도 고려된다. 따라서 산업별 경쟁지수, 시장점유율 등을 추가적인 설명변수로 고려해보는 것도 가능할 것 같다. 이것은 추후의 과제로 남겨둔다. 
한국증권학회지 제49권 6호 (2020)

\section{References}

Ahn, K. H., R. S. Park, and J. W. Park, 2018, The Effect of Credit Rating Changes on Debt Financing: Focusing on The Difference between BIR and AR, The Korean Journal of Financial Engineering, Vol. 17 (2), pp. 23-52.

Ahn, K. H., R. S. Park, C. Hong, and J. Baek, 2016, The Information Effect of BIR and The Financial Constraints, Korean Journal of Financial Studies, Vol. 45 (3), pp. 631-670.

Altman, E. I., 1968, Financial Ratios, Discriminant Analysis and The Prediction of Corporate Bankruptcy, The Journal of Finance, Vol. 23 (4), pp. 589-609.

Altman, E. I., and Rijken, H. A., 2004, How Rating Agencies Achieve Rating Stability, Journal of Banking \& Finance, Vol. 28 (11), pp. 2679-2714.

Bergman, S., M. Hampel, J. Rome, I. Shi, L. Taralli, and X. Yang, 2009, How Standard \& Poor's Arrives At Market Derived Signals, Working Paper, Standard \& Poor's. http://static.stevereads.com/papers_to_read/how_standard_and_poor_arrives_at_mark et_derived_signals_.pdf.

Breger, L. L., L. R. Goldberg, and O. Cheyette, 2003, Market Implied Ratings.: SSRN: https://ssrn.com/abstract $=402800$.

Jeon, S. I., and K. S. Lee, 2015, Debt Contents and The Decision of Corporate Bond Rating, Accounting Information Review, Vol. 33 (1), pp. 1-24.

Jung, Y., and R. S. Park, 2017, Rating Shopping and Incentive Scheme, Korean Journal of Financial Studies, Vol. 46 (4), pp. 755-783.

Jung, Y., and R. S. Park, 2018, The Effect of Information Asymmetry and CRA's Reputation on Bond Yield Spread, Korean Journal of Futures and Options, Vol. 26 (2), pp. 217-245.

Kang, K. H., and J. J. Han, 2013, A Study on Rating Inflation of Korea CRA Industry and Policy Implication, KIF working paper, Vol. 2013 (7), pp. 1-38.

Kang, K. H., Y. S. Bae, and J. J. Han, 2015, An Empirical Study on Credit Rating Inflation in The Korean Corporate Bond Market, Korean Journal of Financial Studies, Vol. 44 (1), pp. 221-245.

Kim, S. H., and T. D. Kim, 2014, A Study on The Overvaluing Behavior of Credit Rating Agency, Review of Accounting and Policy Studies, Vol. 19 (3), pp. 27-49.

Kim, S. S., and J. I. Yoon, 2013, Effect of the Credit Ratings on The Capital Structure, Korean Jouranl of Business Administration, Vol. 26 (8), pp. 2003-2019.

Kisgen, D. J., 2006, Credit Ratings and Capital Structure, The Journal of Finance, Vol. 61 (3), pp. 1035-1072.

Kou, J., and S. Varotto, 2008, Timeliness of Spread Implied Ratings, European Financial 
Determinants and Sensitivity of Credit Ratings

Management, Vol. 14 (3), pp. 503-527.

Löffler, G., 2007, The Complementary Nature of Ratings and Market-based Measures of Default risk, The Journal of Fixed Income, Vol. 17 (1), pp. 38-47.

Longstaff, F. A., S. Mithal, and E. Neis, 2005, Corporate Yield Spreads: Default Risk or Liquidity? New Evidence From The Credit Default Swap Market, The Journal of Finance, Vol. 60 (5), pp. 2213-2253.

Munves, D., D. Hamilton, C. Mann, and M. Woolley, 2007, Moody's Market Implied Ratings Description, Methodology, and Analytical Applications, ViewPoints publication, Moody's Credit Strategy Group. http://efinance.org.cn/cn/FEshuo/Moody\%27s\%20Market\%20I mplied\%20Ratings.pdf.

Na, Y., and D. M. Jin, 2003, Research Papers: On The Usefulness of Financial Information in Forecasting of Credit Ratings: Post IMF, Accounting Information Review, Vol. 21, pp. 211-235.

Oh, S. A., and K. H. Chung, 2015, Comparing The Characteristic of Credit Ratings and Bond Implied Ratings, Review of Financial Information Studies, Vol. 4 (1), pp. 53-79.

Park, K. D., K. S. Han, and S. J. Yoon, 2008, A Study of The Modification on Financial Stability Score Model for Anticipating Credit Ratings, Korea International Accounting Review, Vol. 21, pp. 1-18.

Shin, D. R., 1989, Classification of CP Grades Using Financial Statements, Korea Investors Service Rating Journal, Vol. 2 (1), pp. 68-79.

Tsoukas, S., and M. E. Spaliara, 2014, Market Implied Ratings and Financing Constraints: Evidence From US Firms, Journal of Business Finance \& Accounting, Vol. 41 (1-2), pp. 242-269.

Yeo, E. J., 2012, Policy Articles : The Credit Rating Agencies: Causes of Failures and Their Remedies, Journal of Money \& Finance, Vol. 26 (3), pp. 191-220. 
한국증권학회지 제49권 6호 (2020)

\section{〈부록〉}

〈표 11〉 BIR기준 등급분포

\begin{tabular}{lrrrr}
\hline \multicolumn{1}{c}{ BIR등급 } & $\mathrm{AR}<\mathrm{BIR}$ & $\mathrm{AR}=\mathrm{BIR}$ & $\mathrm{AR}>\mathrm{BIR}$ & \multicolumn{1}{c}{ 전체 } \\
\hline $\mathrm{AAA}$ & $0(0.0 \%)$ & $105(39.8 \%)$ & $159(60.2 \%)$ & $264(100 \%)$ \\
$\mathrm{AA}^{+}$ & $2(0.6 \%)$ & $157(47.9 \%)$ & $169(51.5 \%)$ & $328(100 \%)$ \\
$\mathrm{AA}$ & $9(2.4 \%)$ & $140(37.7 \%)$ & $222(59.8 \%)$ & $371(100 \%)$ \\
$\mathrm{AA}^{-}$ & $44(18.5 \%)$ & $136(57.1 \%)$ & $58(24.4 \%)$ & $238(100 \%)$ \\
$\mathrm{A}^{+}$ & $77(15.8 \%)$ & $314(64.5 \%)$ & $96(19.7 \%)$ & $487(100 \%)$ \\
$\mathrm{A}$ & $82(25.8 \%)$ & $150(47.2 \%)$ & $86(27.0 \%)$ & $318(100 \%)$ \\
$\mathrm{A}^{-}$ & $177(46.2 \%)$ & $194(50.7 \%)$ & $12(3.1 \%)$ & $383(100 \%)$ \\
$\mathrm{BBB}^{+}$ & $283(71.5 \%)$ & $97(24.5 \%)$ & $16(4.0 \%)$ & $396(100 \%)$ \\
$\mathrm{BBB}$ & $83(72.8 \%)$ & $28(24.6 \%)$ & $3(2.6 \%)$ & $114(100 \%)$ \\
$\mathrm{BBB}-$ & $111(81.6 \%)$ & $24(17.6 \%)$ & $1(0.7 \%)$ & $136(100 \%)$ \\
\hline 전체 & $868(28.6 \%)$ & $1,345(44.3 \%)$ & $822(27.1 \%)$ & $3,035(100 \%)$ \\
\hline
\end{tabular}




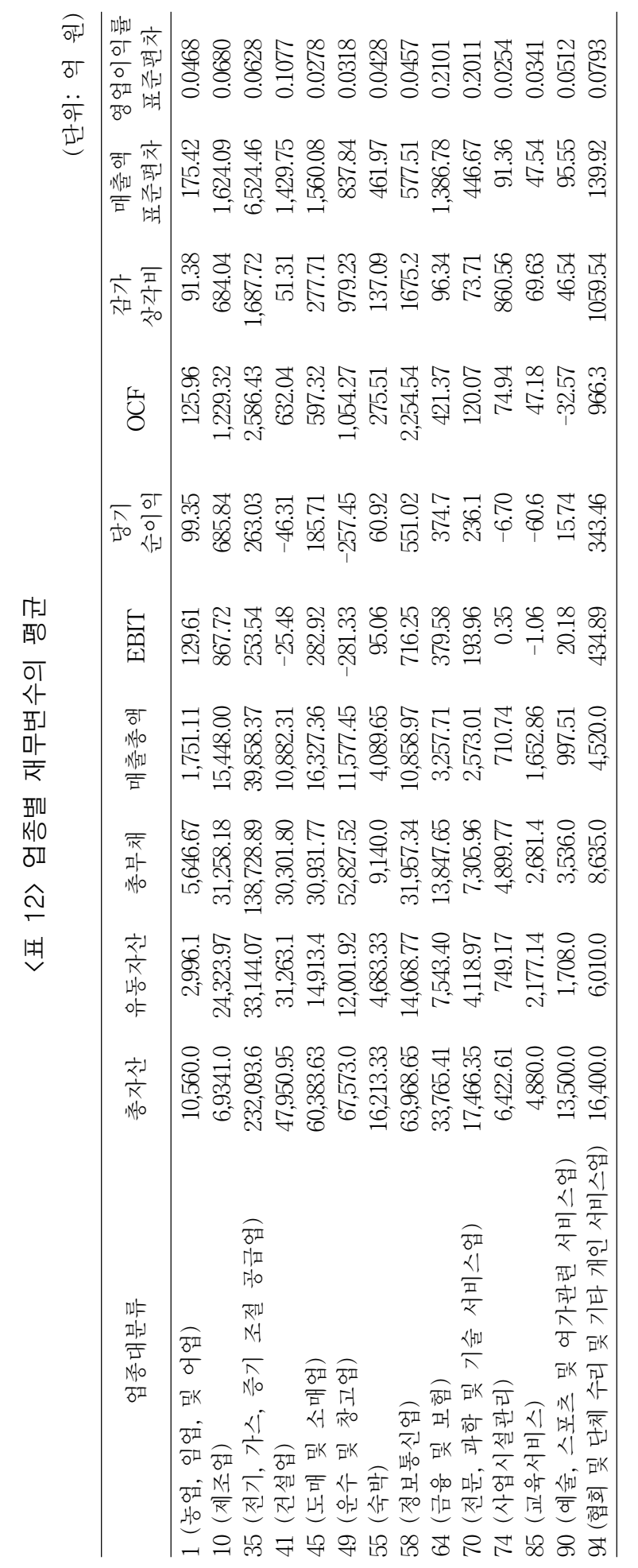


한국증권학회지 제49권 6호 (2020)

〈표 13〉 회귀계수를 오즈비로 변환

표의 내용은 오즈비값을, 괄호안은 $\mathrm{t}$-값을, 그리고 ***, ** *은 각각 $1 \%, 5 \%, 10 \%$ 에서 유의함을 나타낸다.

(재무변수의 단위: 십조 원)

\begin{tabular}{|c|c|c|c|c|c|c|}
\hline & $\begin{array}{l}\text { BIR } \\
(1)\end{array}$ & $\begin{array}{c}\mathrm{BIR} \\
(2)\end{array}$ & $\begin{array}{l}\text { AR } \\
(4)\end{array}$ & $\begin{array}{l}\text { AR } \\
(5)\end{array}$ & $\begin{array}{l}\text { DIFF } \\
(7)\end{array}$ & $\begin{array}{l}\text { DIFF } \\
(8)\end{array}$ \\
\hline 자산 & $\begin{array}{c}0.978^{* * * *} \\
(0.002)\end{array}$ & $\begin{array}{c}0.991^{* *} \\
(0.003)\end{array}$ & $\begin{array}{c}0.974^{* * * *} \\
(0.002)\end{array}$ & $\begin{array}{l}0.960^{* * *} \\
(0.005)\end{array}$ & $\begin{array}{c}1.03^{* * *} \\
(0.001)\end{array}$ & $\begin{array}{r}1.04 \\
(0.003)\end{array}$ \\
\hline 유동자산 & $\begin{array}{l}1.039^{* * *} \\
(0.003)\end{array}$ & $\begin{array}{c}0.984^{* *} \\
(0.007)\end{array}$ & $\begin{array}{l}1.024^{* * *} \\
(0.003)\end{array}$ & $\begin{array}{l}0.960^{\text {**** }} \\
(0.011)\end{array}$ & $\begin{array}{l}1.049^{* * *} \\
(0.003)\end{array}$ & $\begin{array}{c}1.015^{* *} \\
(0.007)\end{array}$ \\
\hline 부채 & $\begin{array}{c}1.026^{* * *} \\
(0.003)\end{array}$ & $\begin{array}{l}1.037^{* * *} \\
(0.006)\end{array}$ & $\begin{array}{l}1.023^{* * * *} \\
(0.003)\end{array}$ & $\begin{array}{l}1.061^{* * *} \\
(0.009)\end{array}$ & $\begin{array}{l}1.022^{* * *} \\
(0.002)\end{array}$ & $\begin{array}{l}1.017^{* * *} \\
(0.005)\end{array}$ \\
\hline 매출 & $\begin{array}{l}0.948^{* * *} \\
(0.004)\end{array}$ & $\begin{array}{l}0.945^{* * *} \\
(0.008)\end{array}$ & $\begin{array}{l}0.959^{* * * *} \\
(0.004)\end{array}$ & $\begin{array}{l}0.920^{\text {*** }} \\
(0.011)\end{array}$ & $\begin{array}{l}0.942^{* * *} \\
(0.004)\end{array}$ & $\begin{array}{c}0.955^{* * *} \\
(0.008)\end{array}$ \\
\hline EBIT & $\begin{array}{r}1.008 \\
(0.067)\end{array}$ & $\begin{array}{c}1.249^{*} \\
(0.098)\end{array}$ & $\begin{array}{r}1.008 \\
(0.068)\end{array}$ & $\begin{array}{r}1.475 \\
(0.143)\end{array}$ & $\begin{array}{r}1.038 \\
(0.071)\end{array}$ & $\begin{array}{c}1.183^{*} \\
(0.117)\end{array}$ \\
\hline 순이익 & $\begin{array}{r}0.939 \\
(0.073)\end{array}$ & $\begin{array}{l}0.747^{* * *} \\
(0.068)\end{array}$ & $\begin{array}{r}0.94 \\
(0.073)\end{array}$ & $\begin{array}{l}0.588^{* * *} \\
(0.066)\end{array}$ & $\begin{array}{r}0.892 \\
(0.073)\end{array}$ & $\begin{array}{c}0.820^{*} \\
(0.096)\end{array}$ \\
\hline OCF & $\begin{array}{r}1.008 \\
(0.016)\end{array}$ & $\begin{array}{r}1.021 \\
(0.018)\end{array}$ & $\begin{array}{r}1.011 \\
(0.016)\end{array}$ & $\begin{array}{l}1.082^{* *} \\
(0.025)\end{array}$ & $\begin{array}{r}1.022 \\
(0.015)\end{array}$ & $\begin{array}{r}0.992 \\
(0.018)\end{array}$ \\
\hline 감가상각비 & $\begin{array}{r}0.967 \\
(0.046)\end{array}$ & $\begin{array}{l}0.790^{* *} \\
(0.095)\end{array}$ & $\begin{array}{l}1.136^{* * *} \\
(0.056)\end{array}$ & $\begin{array}{r}1.261 \\
(0.201)\end{array}$ & $\begin{array}{l}0.820^{* * *} \\
(0.033)\end{array}$ & $\begin{array}{c}0.805^{*} \\
(0.092)\end{array}$ \\
\hline 매출액표준편차 & $\begin{array}{c}0.922^{* * *} \\
(0.014)\end{array}$ & $\begin{array}{l}0.917^{* * *} \\
(0.019)\end{array}$ & $\begin{array}{l}0.924^{* * *} \\
(0.014)\end{array}$ & $\begin{array}{l}0.898^{* * *} \\
(0.024)\end{array}$ & $\begin{array}{l}0.920^{* * *} \\
(0.015)\end{array}$ & $\begin{array}{l}0.924^{* * * *} \\
(0.021)\end{array}$ \\
\hline 영업이익표준편차 & $\begin{array}{r}0.999 \\
(0.058)\end{array}$ & $\begin{array}{r}0.998 \\
(0.073)\end{array}$ & $\begin{array}{c}0.989^{*} \\
(0.063)\end{array}$ & $\begin{array}{c}0.988^{* *} \\
(0.113)\end{array}$ & $\begin{array}{c}1.159^{* * *} \\
(0.059)\end{array}$ & $\begin{array}{r}1.011 \\
(0.073)\end{array}$ \\
\hline 산업활동지수 & $\begin{array}{r}1.022 \\
(0.015)\end{array}$ & $\begin{array}{l}1.049^{* * * *} \\
(0.018)\end{array}$ & $\begin{array}{r}0.991 \\
(0.015)\end{array}$ & $\begin{array}{r}0.971 \\
(0.019)\end{array}$ & $\begin{array}{l}1.051^{* * *} \\
(0.017)\end{array}$ & $\begin{array}{l}1.066^{* * *} \\
(0.023)\end{array}$ \\
\hline MMF & $\begin{array}{r}0.468 \\
(0.465)\end{array}$ & $\begin{array}{r}0.898 \\
(0.985)\end{array}$ & $\begin{array}{r}0.436 \\
(0.434)\end{array}$ & $\begin{array}{r}0.827 \\
(1.038)\end{array}$ & $\begin{array}{r}1.349 \\
(1.457)\end{array}$ & $\begin{array}{r}1.767 \\
(2.362)\end{array}$ \\
\hline M2 & $\begin{array}{l}0.002^{* * *} \\
(0.004)\end{array}$ & $\begin{array}{l}0.000^{* * *} \\
(0.000)\end{array}$ & $\begin{array}{r}1.156 \\
(2.322)\end{array}$ & $\begin{array}{r}24.937 \\
(65.550)\end{array}$ & $\begin{array}{l}0.000^{* * *} \\
(0.000)\end{array}$ & $\begin{array}{l}0.000^{* * * *} \\
(0.000)\end{array}$ \\
\hline KORIBOR_3개월 & $\begin{array}{r}1.606 \\
(0.542)\end{array}$ & $\begin{array}{c}2.101^{*} \\
(0.797)\end{array}$ & $\begin{array}{r}1.374 \\
(0.460)\end{array}$ & $\begin{array}{r}0.9 \\
(0.376)\end{array}$ & $\begin{array}{r}1.54 \\
(0.559)\end{array}$ & $\begin{array}{r}1.475 \\
(0.700)\end{array}$ \\
\hline 국채금리1년 & $\begin{array}{r}0.663 \\
(0.272)\end{array}$ & $\begin{array}{r}0.609 \\
(0.279)\end{array}$ & $\begin{array}{r}0.714 \\
(0.292)\end{array}$ & $\begin{array}{r}0.891 \\
(0.452)\end{array}$ & $\begin{array}{r}0.773 \\
(0.337)\end{array}$ & $\begin{array}{r}0.713 \\
(0.406)\end{array}$ \\
\hline 국채금리5년 & $\begin{array}{r}1.176 \\
(0.172)\end{array}$ & $\begin{array}{r}1.222 \\
(0.200)\end{array}$ & $\begin{array}{r}1.266 \\
(0.186)\end{array}$ & $\begin{array}{l}1.950^{* * *} \\
(0.363)\end{array}$ & $\begin{array}{r}1.054 \\
(0.167)\end{array}$ & $\begin{array}{r}0.995 \\
(0.200)\end{array}$ \\
\hline 경제성장률 & $\begin{array}{r}0.941 \\
(0.088)\end{array}$ & $\begin{array}{r}0.88 \\
(0.093)\end{array}$ & $\begin{array}{r}0.96 \\
(0.089)\end{array}$ & $\begin{array}{r}0.885 \\
(0.105)\end{array}$ & $\begin{array}{r}0.906 \\
(0.092)\end{array}$ & $\begin{array}{r}0.869 \\
(0.112)\end{array}$ \\
\hline 순상품교역조건지수 & $\begin{array}{l}1.043^{* * *} \\
(0.015)\end{array}$ & $\begin{array}{l}1.109^{* * *} \\
(0.018)\end{array}$ & $\begin{array}{r}1.018 \\
(0.015)\end{array}$ & $\begin{array}{c}1.061^{\text {*** }} \\
(0.019)\end{array}$ & $\begin{array}{c}1.035^{* *} \\
(0.016)\end{array}$ & $\begin{array}{c}1.058^{* * * *} \\
(0.021)\end{array}$ \\
\hline $\mathrm{N}$ & 3,035 & 3,035 & 3,035 & 3,035 & 3,035 & 3,035 \\
\hline
\end{tabular}

